Tesis de Maestría en Comunicación y Derechos Humanos

\title{
LA MEMORIA DEL GENOCIDIO ARMENIO A TRAVÉS DE LA ESCUCHA.
}

Rastros de la negación y el negacionismo en sobrevivientes y descendientes de la diáspora armenia en la Argentina.

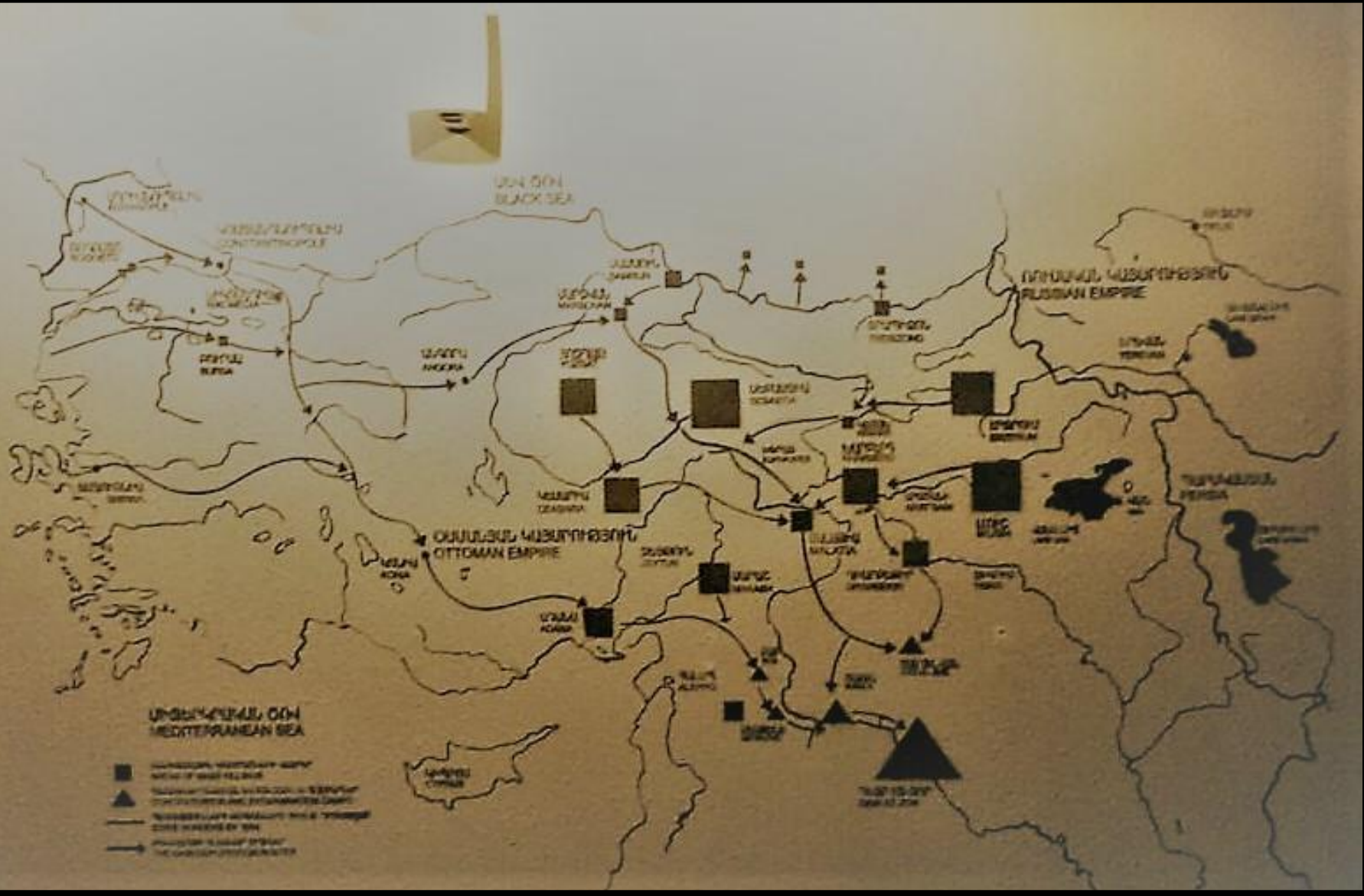

Silvana Analía Kechichian 
UNIVERSIDAD NACIONAL DE LA PLATA

FACULTAD DE PERIODISMO Y COMUNICACIÓN SOCIAL MAESTRÍA EN COMUNICACIÓN Y DERECHOS HUMANOS

LA MEMORIA DEL GENOCIDIO ARMENIO A TRAVÉS DE LA ESCUCHA. Rastros de la negación y el negacionismo en sobrevivientes y descendientes de la diáspora armenia en la Argentina.

2021

Maestranda: Silvana Kechichian

Directoras: María Eugenia Ludueña y Ana Arzoumanian 
Para mi hija Rocío 
ÍNDICE.

Presentación 1

Introducción 4

PRIMER MOMENTO. Los documentos oficiales ante los tribunales otomanos: 13 1918-1921.

$\begin{array}{ll}\text { Lengua y Memoria. El borramiento. } & 21\end{array}$

SEGUNDO MOMENTO. La declaración del acusado que se convirtió en $\quad 26$ testimonio de sobreviviente. Berlín 1921.

Identidad y conflicto. La tolerancia y el respeto. 33

La diáspora armenia entre la negación y el negacionismo. 39

Coordenadas de regreso. 42

TERCER MOMENTO. La búsqueda de testimonios por el Derecho a la 46

Verdad. Buenos Aires 2001-2011.

CUARTO MOMENTO. Escuchar a los sobrevivientes en Buenos Aires. 53

Lo que dice Dikrauni.

Los Jóvenes turcos de Armen. $\quad 58$

Los 92 años de Guiragoz.

Guiragoz, el orfanato y las canciones. $\quad 68$

$\begin{array}{ll}\text { Voces y territorios. } & 77\end{array}$

$\begin{array}{ll}\text { Reflexiones. } & 75\end{array}$

Bibliografía. $\quad 79$ 


\section{Presentación}

La identificación de los sitios de memoria a través de la escucha de los testimonios de sobrevivientes del genocidio armenio y sus descendientes que conforman una parte de la diáspora armenia, - en este caso en la Argentina -, es un ejercicio de reparación simbólica.

La puesta en valor tanto del silencio como de las voces de quienes hoy ya no están permite una alianza con los lugares de la llamada Armenia histórica occidental. Un puente hacia los lugares enterrados con violencia entre los años 1915 y 1923 . Violencia que continúa en el negacionismo turco a más de un siglo de la imposibilidad de justicia y reparación.

Los capítulos que conforman este ejercicio de memoria a través de la escucha se presentan en función de los rastros de la negación y del negacionismo, en sobrevivientes y descendientes de la diáspora armenia en la Argentina partiendo de una experiencia personal: comprobar que el silencio se resignifica en la escucha.

Mis abuelos paternos eran de origen armenio, sobrevivientes de Yozgat, uno de los pueblos de aquella Armenia histórica occidental que se encuentra en Turquía actual. Nunca hablaron con sus hijos y nietos sobre el trauma de haber sido deportados hacia Siria y más allá, llegando a El Líbano.

Debido a ello; en este trabajo se potencia el hecho de que entre los años 2006 y 2008 , donde ya casi no había sobrevivientes en Buenos Aires, se creara un archivo oral sobre la memoria del genocidio armenio para ser utilizado en un juicio contra el Estado turco. Hay antecedentes paradigmáticos que se relevan aquí para dar cuenta de las deficiencias que el derecho penal internacional arrastra desde la Primera Guerra Mundial.

Sin embargo no es suficiente, las fuentes escritas y orales necesitan ser ubicadas no sólo en tiempo sino fundamentalmente en espacio; para este ejercicio de reparación simbólica 
el territorio debe manifestarse. Por eso, en este trabajo, el ejercicio de memoria se completa a través de la cartografía. 


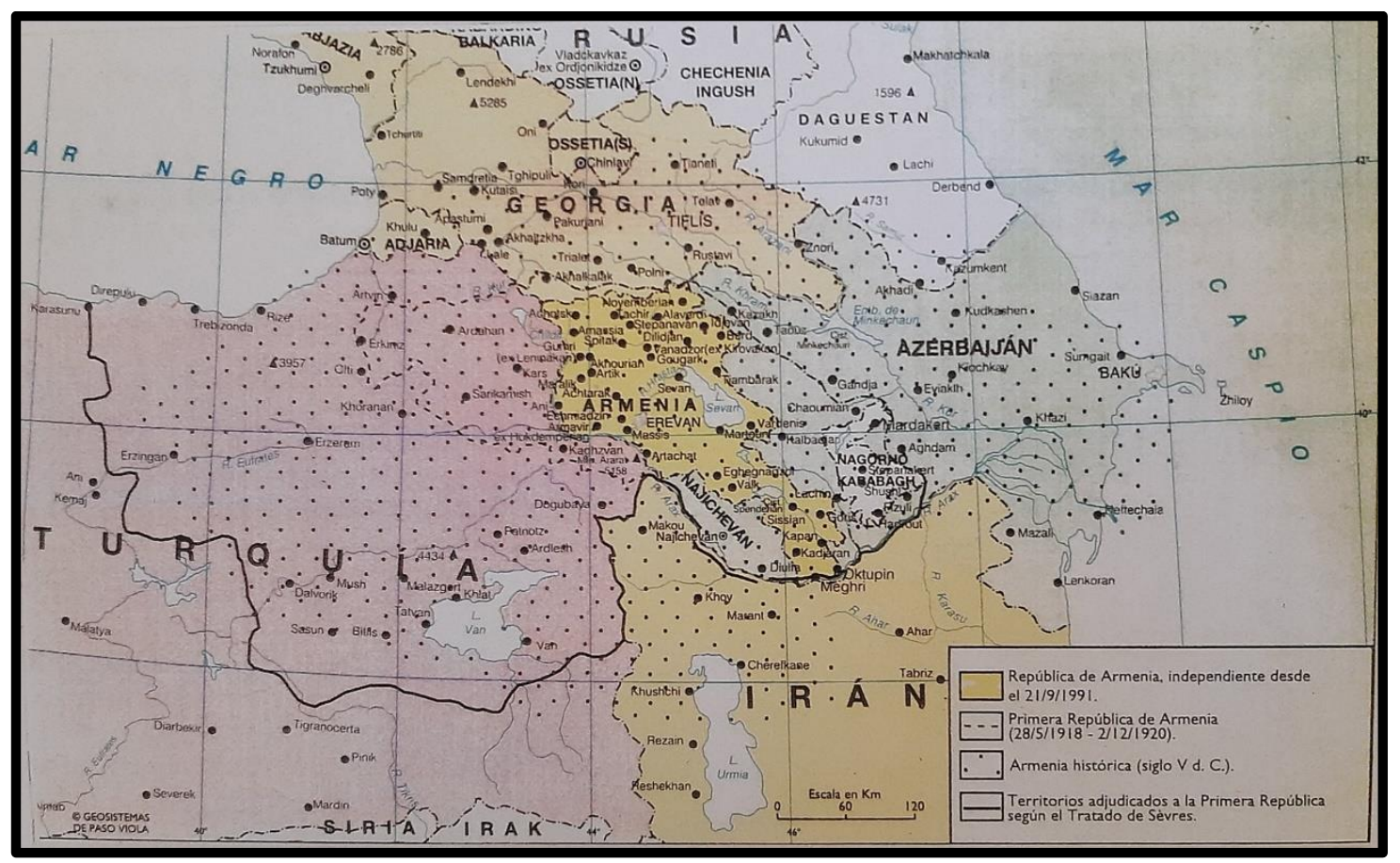

Fuente: Armenia, una cultura milenaria en la Argentina, Buenos Aires, Ediciones Manrique Zago, 1999. Coordinación general e investigación histórica e iconográfia, Nélida Boulgourdjian-Toufeksian ; asesoría general, Rubén Mozian ; coordinación editorial, Rita M. Veneroni ; textos, Carlos Alemian.

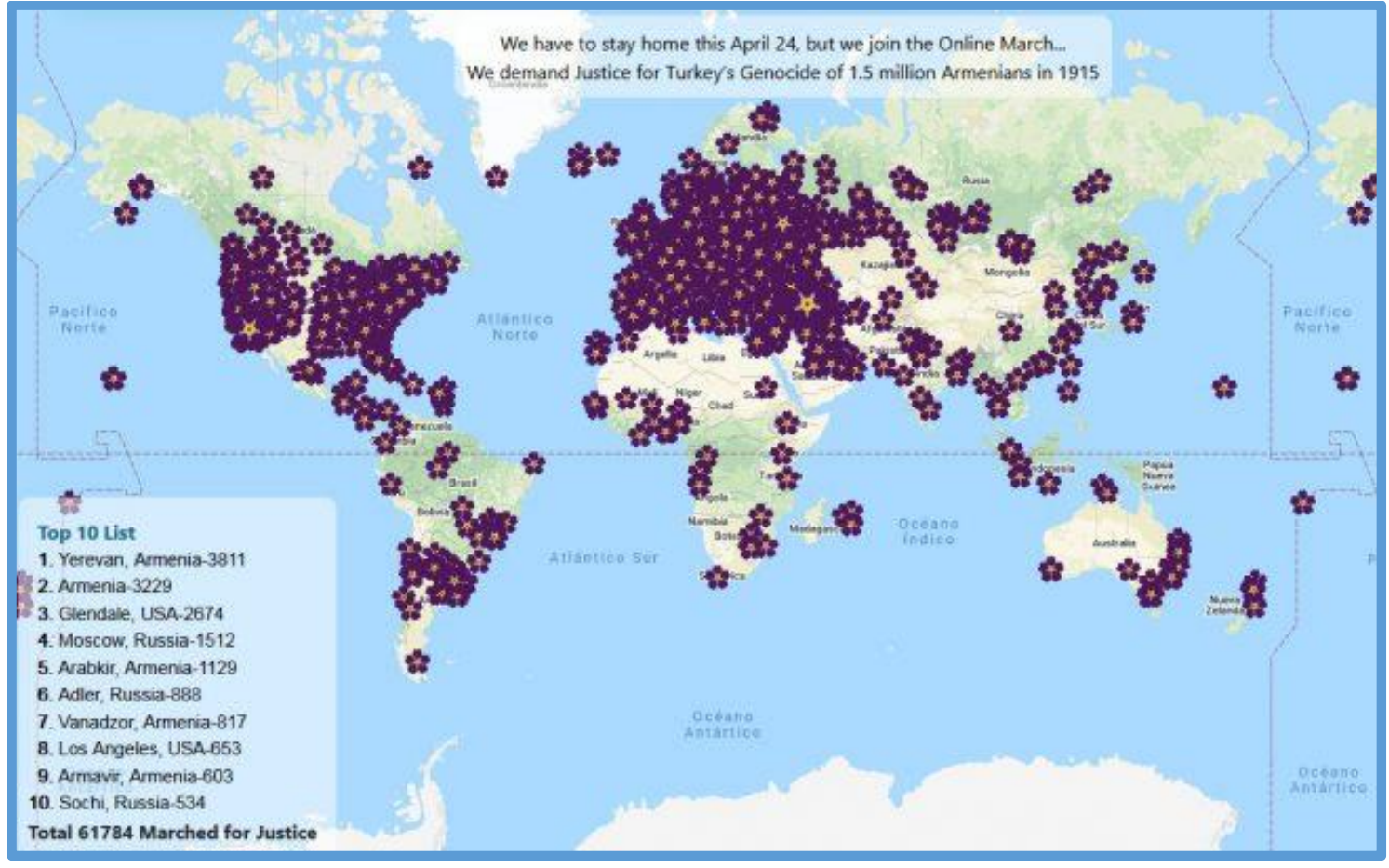

Fuente: La organización HyeID lanzó en el año 2020 una plataforma para organizar una "marcha digital mundial" en el $105^{\circ}$ aniversario del Genocidio Armenio en el contexto de pandemia mundial. Este mapa representa la participación de la diáspora armenia el 24 de abril día en el que se conmemora el genocidio armenio con la flor de Nomeolvides. 


\section{Introducción}

Las voces que partieron desde los territorios donde se produjo el genocidio armenio pueden transformarse en líneas subterráneas, y esas líneas pueden escucharse creando una dimensión que permita anidarlas. Si esto es posible podremos recuperar, en parte, un legado que como descendientes de los sobrevivientes nos es negado.

Los armenios que llegaron a nuestro país tras la Primera Guerra Mundial trajeron un debate acerca de su condición de inmigrantes, refugiados, exiliados, expatriados. Vinieron desde Asia y Europa en distintas “oleadas". 1

Adelantando varios pasos distinguiendo dichos conceptos - y aplicándolos con rigor a la luz de la discusión acerca de las limitaciones al reconocimiento de una nacionalidad, según el lugar de procedencia en un contexto de posguerra y fragmentación del Imperio Otomano -, podemos establecer que quienes llegaron en las primeras oleadas durante el primer tercio del siglo XX a la Argentina, fueron sobrevivientes de un genocidio. ${ }^{2}$

\footnotetext{
${ }^{1}$ Brisa Varela en su tesis doctoral "Los rostros de Haig” Memoria, migración e identidades a principios del siglo XXI, Buenos Aires, FLACSO, 2006, aborda la relación existente entre los procesos de globalización y mundialización con las migraciones de armenios hacia la Argentina. Compara la habitud entre los descendientes de la diáspora histórica, llegada a nuestro país a principios del siglo XX y los nuevos inmigrantes, que arriban a fines del mismo siglo tras el particular caso de los países ex integrantes de la URSS, la actual República de Armenia, que no incluye la Armenia Histórica Occidental.

2 En 1948: “El delito de genocidio, según la definición de la Convención para la Prevención y Sanción del Delito de Genocidio de las Naciones Unidas, comprende "cualquiera de los siguientes actos cometidos con la intención de destruir, en todo o en parte, a un grupo nacional, étnico, racial o religioso tales como matanza de miembros del grupo, lesión grave a la integridad física o mental de los miembros del grupo, sometimiento intencional del grupo a condiciones de existencia que hayan de acarrear su destrucción física, total o parcial, medidas destinadas a impedir los nacimientos en el seno del grupo, traslado por fuerza de niños del grupo a otro grupo. Por su naturaleza, evidentemente, el genocidio es un crimen planificado cuya instrumentación requiere de una pluralidad de actores. Es una violación al derecho a la vida que expresa la negación absoluta de la calidad y dignidad del ser humano y que, por ello mismo, vuelve víctima a la humanidad en su
} 
Los descendientes sostenemos el reclamo que el poder no resuelve. Somos emergentes de las voces y los territorios que llevan las marcas de los acontecimientos pendientes de juzgar y de reparar.

El negacionismo ${ }^{3}$ se puede observar en la diáspora armenia de distintas formas según el modo de apropiación y de interacción en la comunidad armenia de Buenos Aires.

En mi caso, el modo de apropiación y de interacción se inicia a partir de encontrar los objetos y documentos de mis abuelos paternos de origen armenio, quienes llegaron a la

conjunto. Tamaña empresa resulta inimaginable de no existir cierta cuota de complicidad, revestida de indiferencia o de silencio, pero constitutiva de la garantía de impunidad. De aquí que, conocer y dar a conocer la historia es un derecho fundamental de las víctimas, pero también un deber de los contemporáneos respecto de las generaciones futuras." En Feierstein, Daniel. Genocidio, La administración de la muerte en la modernidad, EDUNTREF, Buenos Aires, 2005.

3 "Que la naturaleza problemática del término "genocidio" ha sido utilizada por quienes niegan el genocidio está demostrado por Hovannisian (1998). Él cita a Justin McCarthy, quien niega el genocidio de Armenia, por decir que "Genocidio es una palabra de gran poder y valor propagandístico. Es también una palabra con muchas definiciones imprecisas... Sería mucho mejor estudiar la historia de los armenios y los turcos como una gran pérdida humana, y abandonar los términos propagandísticos". Por su parte, Lemkin dejó en claro cuando describió el proyecto de la CONUG: La experiencia nazi no constituyó una base suficiente para una definición de genocidio a los fines internacionales. No se puede describir un delito a través de una sola experiencia delictiva; (más bien) se debería recurrir a todas las experiencias disponibles en el pasado. La definición de un delito que involucra la participación de sociedades debe adaptarse a todas las estructuras sociales. (...) En síntesis, la formulación debe ser válida para todos los tiempos, todas las situaciones y todas las culturas.

Los Tribunales ad hoc seguirán identificando y enjuiciando a los perpetradores y a los cómplices de genocidio y otros delitos. Al hacerlo ayudarán a combatir la cultura de la impunidad que ha rodeado y protegido a los genocidas en el pasado, y bien pueden ayudar tanto a los individuos como a las sociedades afectadas a recuperarse de los horrores del pasado y a prevenir futuras tragedias. Asimismo, una definición clara y ampliamente reconocida podría tal vez ayudar a hacer que la negación de genocidio sea más complicada si se modifica el hecho de que " En ausencia de una resolución jurídica o una decisión política, prácticamente cualquier caso de genocidio pueda ser cuestionado" Nota 119 Orentlicher, en Gutman y Rieff, eds., 1999, p. 157. En Feierstein Daniel. "Genocidio: La administración de la muerte en la modernidad" EDUNTREF. Buenos Aires. 2005 
Argentina a fines de la década del 20' del siglo pasado. Ellos ya habían muerto cuando los recuperé y descubrí su lugar de nacimiento; Yozgat. No lo supe antes por transmisión oral/intrafamiliar, ni por pertenencia institucional.

Si bien hay estudios que sostienen que; "En la cultura armenia tradicional, la imagen del hombre está caracterizada por el valor máximo otorgado a su ingenio de sobrevivir, una prioridad casi absoluta. Todo lo demás sirve a este objetivo y por esa misma causa es menos importante. Estos valores son fuertes lazos familiares y nacionales, confianza en las emociones, moral de trabajo duro y sacrificio, amor a la iglesia y a la tierra (ancestral), fuerte sentimiento de particularidad nacional y de ser diferente al resto del mundo, atadura a los valores morales (...) El país se transforma en el origen de los Abuelos" ", esta circunstancia en algún momento comenzó a incomodarme, ¿cómo? por la imposibilidad de haberlos escuchado en primera persona o a través de sus hijos.

Para subsanar en parte esta carencia estudio cómo me "hablaron" a través de sus cosas; sus pasaportes, certificación judicial, certificado de embarque, postales con fotografías y escritos, diarios, discos, libros. Interpreto ese código, ese silencio. Y fue con la identificación de esas coordenadas que pude establecer su condición de sobrevivientes de aquel genocidio.

Por eso, hace más de 18 años comencé "la investigación" y gesté la idea de que mi hija fuera la primera de toda la familia que estudiara en un colegio armenio desde nivel inicial. ¿Consecuencia del negacionismo, una oportunidad para contrarrestarlo o lectura sensible?

Empecé por leer varias historias de vida, relatos de vida, fuentes históricas, ensayos e investigaciones sobre el tema, además de ver algunos documentales y películas. Encontré esos diferentes modos de construir y describir la identidad armenia. Pero sobre todo

\footnotetext{
${ }^{4}$ Oshagan Vahé, “Armenian american, contribution to America”, Hromglá, vol. 2 .1983. p. 200, citado en Manrique Zago (ed,) “Armenia, una presencia milenaria en la Argentina”, Buenos Aires, Manrique Zago, 1999.
} 
encontré esa pertenencia que se transformó en un desafío. Mi origen armenio se extendió hacia la armenidad "institucionalizada" de mi hija y llené de voces ese silencio ancestral. Encontré la interacción con otros modos de apropiación de la armenidad.

Sin embargo, en 2016 viajé a Armenia, a la Madre Patria, sin poder (desde allí) "cruzar" a Turquía, el territorio donde nacieron mis abuelos, Yozgat. ¿Tenía acaso acceso al territorio estando allí? ¿A esos lugares de la memoria? Ese silencio que transformé en muchas voces volvió multiplicado mirando el Monte Ararat ${ }^{5}$ desde la frontera cerrada entre los dos países. La República de Armenia actual responde a los límites de la ex República Socialista Soviética, en base a la llamada Armenia Histórica ésta es la Armenia Oriental que logró su primera independencia el 28 de mayo de $1918 .{ }^{6}$

Allí el odio en forma de masacre y deportación, entre otras acciones genocidas que se perpetraron, no penetró directamente. Esta República es la Armenia que está en el fuego cruzado con Azerbaiyan. ${ }^{7}$ La Armenia que tiene la frontera cerrada hacia la parte occidental de sus tierras ancestrales.

El territorio se manifestó, escuché el silencio, esa "armenidad" de mis abuelos.

\footnotetext{
${ }^{5}$ El Monte Ararat es el lugar mítico en la historia bíblica de los armenios que se describe en el Génesis, es el lugar donde el Arca de Noé encalló después del gran diluvio. Este hecho da origen al nombre del territorio que Haig, descendiente de Noé, consolidó para el pueblo armenio desde el tercer milenio antes de Cristo. De allí el nombre Haiastan, Armenia.

${ }^{6}$ Período que duró hasta 1921 cuando se incorpora a la URSS, hasta su segunda independencia el 21 de septiembre de 1991.

${ }^{7}$ Me refiero a la Guerra entre 1988 y 1994 con Azerbaiyán por el territorio de Nagorno Karabagh (Artsaj) un enclave armenio en territorio azerí, en pleno período de fragmentación de la URSS. La autoproclamación de independencia de Artsaj sigue a la espera del reconocimiento internacional. Al momento de concluir esta tesis el conflicto escaló a una nueva guerra a partir del 27 de septiembre de 2020. A modo de reseña se puede consultar https://www.diarioarmenia.org.ar/resumen-de-la-guerra-de-artsaj-y-el-acuerdo-firmado.
} 
"Los descendientes de los sobrevivientes crecieron en un entorno donde el silencio imperaba como una fuerte carga sobre todos, donde ninguna palabra podía aludir a la mención de aquellos muertos. "8

No era sólo solemnidad e ignominia, era la violencia que sigue ejerciendo el negacionismo turco. ¿Qué hacer frente a esta violencia negacionista? Decidí acudir a las voces que fueron arrancadas de ese territorio, de algún modo, enraizarlas y ¿entrar en contradicción? O superar la lejana contradicción con el Otomanismo para insistir en visibilizar nuestras raíces.

Llegar al territorio escuchando esas voces es un derecho que se pone de relieve en los pocos testimonios registrados. Se trata de completar el circuito: escuchar lo que mis abuelos no contaron, escuchar lo que otros sí pudieron, escuchar a los sobrevivientes en un marco que no pudo ser jurídico, pero que pueden permitirse un marco poéticopolítico si encuentro la forma de llegar hasta "allí".

Las entrevistas a los sobrevivientes del Genocidio Armenio que se recrean en este trabajo, cumplirán parte de ese objetivo: "regresar" a la tierra de nuestros abuelos a través de las voces y testimonios, detectando algunas coordenadas. Escuchar para regresar, regresar para conocer, conocer para apropiarse. Ejercer la memoria y la condena del genocidio. ${ }^{9}$

\footnotetext{
${ }^{8}$ Kuyumciyan, Rita C. "El primer genocidio del siglo XX" Regreso de la memoria armenia. Planeta, Buenos Aires. 2009. La autora describe las vertientes del silenciamiento, corrientes antagónicas como lo son los grupos que lo sostienen. Por un lado, está el silencio de los victimarios y por otro, el de las víctimas. El primero está basado en la conciencia de un plan secreto y siniestro de terror de Estado; y el segundo, en el dolor y la indefensión que impone el sinsentido en el que es sumido aquel a quien le afecta tal plan irracional.
}

${ }^{9}$ Distintas legislaciones a nivel internacional condenan el genocidio armenio. Turquía ejerció una política activa de presiones y extorsiones orientadas hacia los organismos internacionales y los estados soberanos para que no reconozcan el genocidio armenio. Así es que recién en 1985 la Subcomisión de Prevención de las Discriminaciones y Protección a las Minorías de Naciones Unidas aceptó calificar el caso armenio como un genocidio, se suman Francia, Uruguay, Argentina, el parlamento europeo, y los de Grecia, Bulgaria, Rusia, Líbano, Chipre, Italia, Lituania, Polonia, Rusia, Eslovaquia, Suecia, Canadá, Siria, Alemania, el 
Caminar la relación de la diáspora armenia en Buenos Aires con la República de Armenia y con la Armenia histórica occidental, actual Turquía, es una tarea compleja. Por eso la relación de la diáspora con la Madre Patria es una cuestión que no profundizaré en este trabajo. Me detendré en la relación con los lugares de la memoria de la Armenia histórica occidental.

El ejercicio se enmarca en la selección e historización de eventos jurídicos en torno a la cuestión del genocidio armenio que tienen como hilo conductor la imposibilidad/posibilidad/oportunidad de presentar fuentes y testimonios de los sobrevivientes ante distintos tribunales. A estas instancias las denominaré los Tres Momentos, para arribar a un Cuarto Momento poético - político que ponga en valor las voces y los territorios. Esta disrupción de los datos duros se basa en la necesidad de visibilizar el vínculo con las tierras ancestrales y sus marcas en la dinámica de la identidad armenia. Aparecerá entonces otra cronología: la cartográfica. ${ }^{10}$

También cierta disrupción en el relato; una plataforma de espacio y tiempo inmaterial que es la memoria. La escucha del silencio y los testimonios que se registraron en los últimos años de vida de los sobrevivientes de la Armenia histórica occidental, se convierte en la narrativa del acercamiento a aquellos lugares a través de un vínculo sensible (imaginario) con la tierra ancestral.

En este sentido se trata de una incipiente narrativa en clave geopoética ${ }^{11}$ donde el territorio se observa, se presenta, se muestra, se lee, se inspecciona, se interviene: se

Vaticano, Chile, Canadá, Venezuela, el Consejo Mundial de Iglesias y el Tribunal Permanente de los Pueblos. Un total de 22 países entre los 193 que integran la ONU.

${ }^{10}$ Una tercera cronología posible para analizar es la legislativa. Un hito en nuestro país es la Ley 26.199, promulgada en el 2007, que establece el 24 de abril de todos los años como el Día de acción por la tolerancia y el respeto entre los pueblos en conmemoración del genocidio de que fue víctima el pueblo armenio.

${ }^{11}$ Concepto y lenguaje creado por el poeta y pensador franco-escocés Kenneth White a fines de los años setenta. «El acento aquí no está puesto en la definición, sino en el deseo, un deseo de vida y de mundo; y 
escucha. El acceso a la memoria del territorio ancestral se convierte así en un ejercicio de "arqueología imaginaria". Es el lugar que dio origen, desarrollo, cultura y en este caso el que también marcó el destierro. Señalizar esas marcas a través de la escucha es visibilizar de qué hablamos cuando trabajamos identidad y memoria del pueblo armenio atravesada por el negacionismo.

La mayoría de los mapas que fueron seleccionados para este trabajo fueron relevados del Atlas histórico mundial realizado por Hermann Kinder y Werner Hilgemann, traducido del alemán y publicado en Madrid por Istmo en 1971, (en su primera edición, ambos tomos se reeditaron hasta el 2005). En todos ellos se rastrea el nombre de Armenia, en un recorrido desde el siglo XX hasta el tercer milenio antes de Cristo. Están trabajados e ilustrados, intervenidos con líneas, formas y colores que permiten leer los contextos histórico-geográficos. Es decir que finalizada esta introducción los mapas que se presentan no fueron elaborados por instituciones armenias (como es el caso de los tres primeros). Consideré conveniente resaltar el hecho de utilizar un Atlas que ha servido a muchas generaciones de estudiantes donde lo relevado se presenta como parte de los grandes procesos sociales, económicos, políticos y religiosos a nivel mundial para evitar que la fuente sea objetable desde la mirada turca o armenia. Seguramente ese análisis forme parte de un estudio posterior.

"El territorio por sí mismo se abre al concurso de las diversas disciplinas y con flexibilidad se adapta a las nuevas condiciones en las que la globalización sitúa al espacio como una dimensión que adquiere la misma preponderancia de la dimensión temporal. El territorio se convierte en la representación del espacio, el cual se ve sometido a una transformación continua que resulta de la acción social de los seres

\footnotetext{
también en el impulso». No se trata de fundar un movimiento literario, sobre todo porque lo «poético» no se toma aquí en su definición de «relativo a la poesía», sino en el sentido de una «formación y dinámica fundamentales» susceptibles de manifestarse tanto en las ciencias como en las artes o el lenguaje. Tampoco se trata de fundar un sistema, al contrario: es un quedarse en lo abierto, rechazando cualquier dogmatismo. La teoría geopoética es inseparable de su práctica, es «una idea de base que no se puede definir in abstracto, sino que surge en vivo, a partir de una pluralidad de contextos». En Cuadernos de geopoética https://www.institut-geopoetique.org/es/articulos/214-breve-introduccion-a-la-geopoetica
} 
humanos, de la cultura y de los frutos de la revolución que en el mundo del conocimiento se vive en todos los rincones del planeta. (...) Las tensiones sociales en los territorios, en ellos más que la homogeneidad, lo que se busca es encontrar la singularidad, la particularidad que le dará identidad al territorio. " 12

${ }^{12}$ Llanos Hernandez, Luis, "El concepto de territorio y la investigación en las ciencias sociales" en Agricultura, sociedad y desarrollo vol. 7 núm. 3. México, Revista Digital Scielo, 2010. 

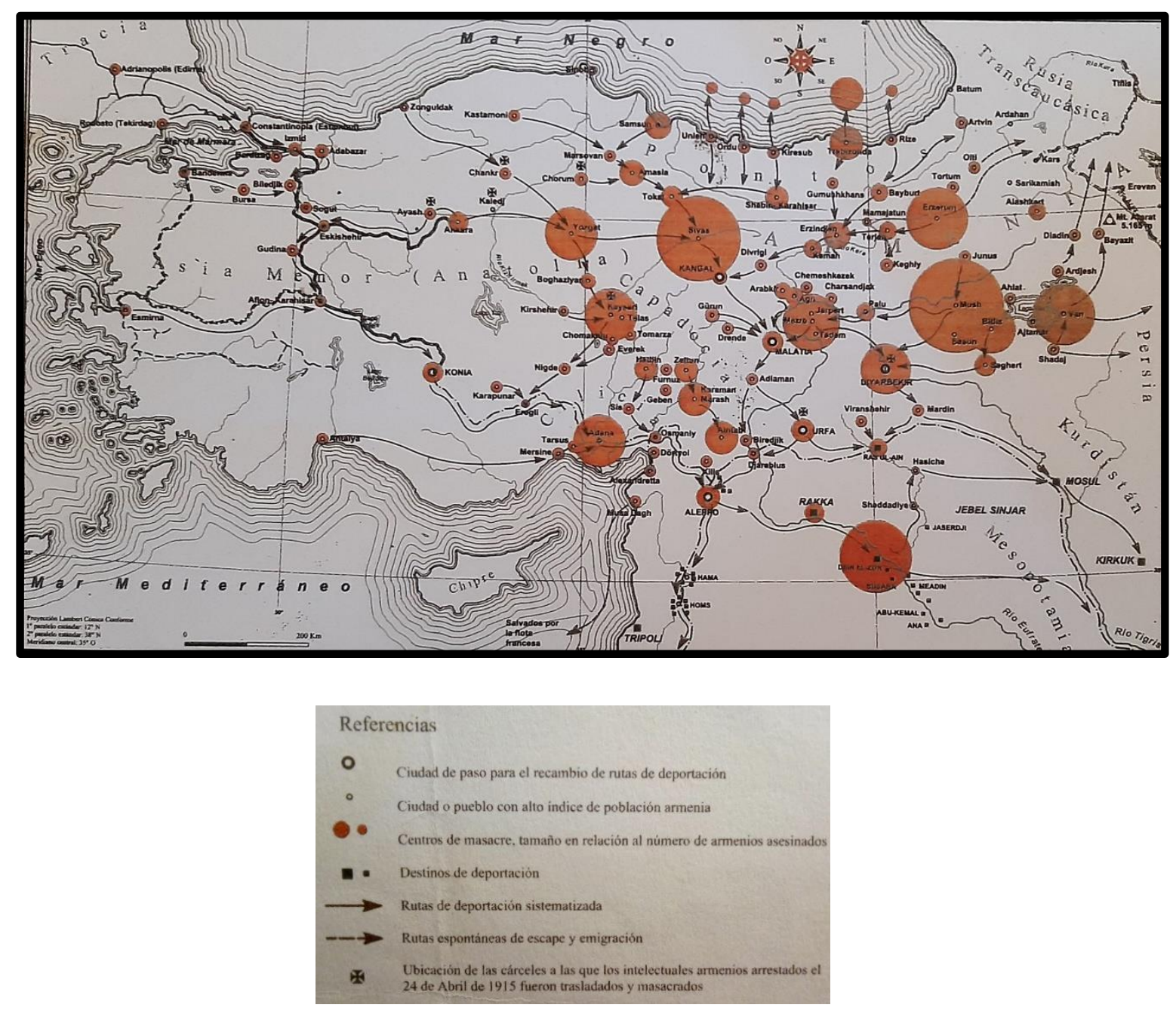

Fuente: El Genocidio Armenio durante la caída del Imperio Otomano y la formación de Turquía Moderna: Deportación y Aniquilación Sistemática de la población armenia desde 1890 a 1923. Centro de Estudios e Investigaciones Urartu www.genocidioarmenio.org 


\section{PRIMER MOMENTO}

\section{Los documentos oficiales ante los Tribunales otomanos: 1918-1921.}

El Alto Comisionado de la República Francesa en Siria y El Líbano emitió los pasaportes de mis abuelos paternos para viajar al extranjero -válidos por un año-, tanto a Hovannés como a Aganie. Sin embargo, como se puede ver en cada pasaporte fue en Yozgat, Imperio Otomano, donde nació Hovannés en el año 1900 y también Aganie en 1910. Los armenios eran súbditos otomanos, ciudadanos de segunda; condición de las minorías del Imperio en aquellos tiempos. ${ }^{13}$

Puesto que Siria y El Líbano estaban bajo el Protectorado Francés en la época en que realizaron estos trámites (1928-1929); se solicitó a las autoridades civiles y militares de la República Francesa de Siria y El Líbano el libre tránsito de los titulares de los pasaportes. En ambos casos acerca de su origen se completa: Turquía, mi abuelo naturalizado sirio y mi abuela naturalizada libanesa. Se autorizó el destino: Argentina. Están sellados, precisamente, por la Dirección de Inmigración y Visados por el Consulado Argentino en Beyrouth. Los motivos: por un lado, Hovannes emigró para trabajar y Aganie, - junto a Nahabed de ocho meses según se consigna y observa en la fotografía para reunirse con su esposo.

\footnotetext{
${ }^{13}$ Se pueden mencionar tres partidos políticos armenios en ese contexto: Hindchac, Dashnac y Ramcavar. Por el lado del partido Hindchac se proponía la liberación de Armenia turca y la creación de un Estado independiente; su programa y su ideología eran los de los social-demócratas rusos. El partido obedeció luego a los comunistas y se estima que el régimen soviético lo ha absorbido, por decirlo de algún modo. El Dashnac-sutiún (la Federación) en su programa incluía la creación de dos Armenias autónomas, una federada con Turquía, la otra con Rusia. Después de la sovietización de Armenia no aceptaron la influencia de la URSS. Sus Comités Centrales funcionan hoy en los Estados Unidos, en Francia, en Brasil, en Egipto, en Grecia, en el Líbano, en Siria y en el Irán. Ver más en Alem, Jean Pierre, "Armenia" Biblioteca Asia y África. Eudeba, Buenos Aires.1983.
} 


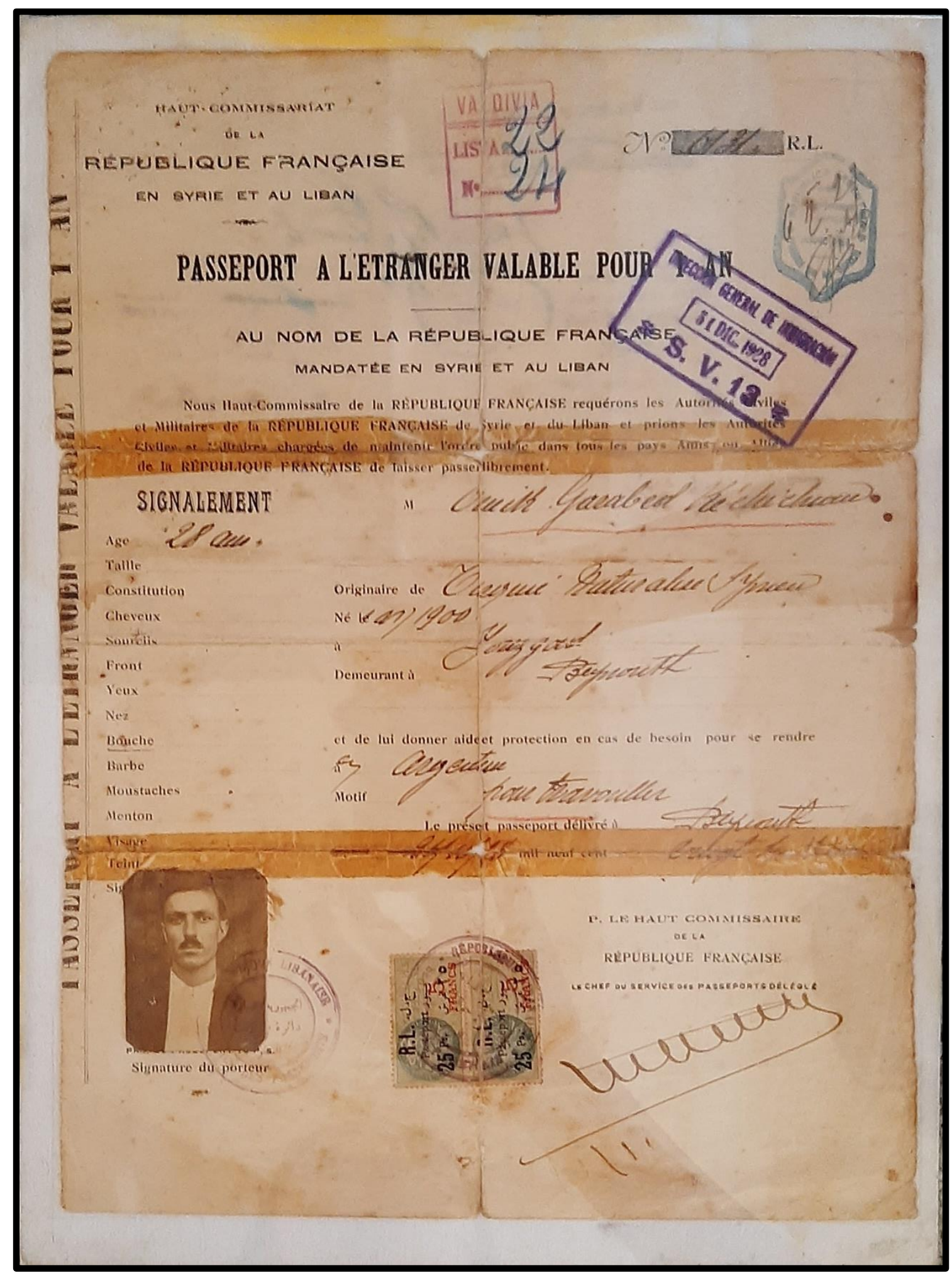




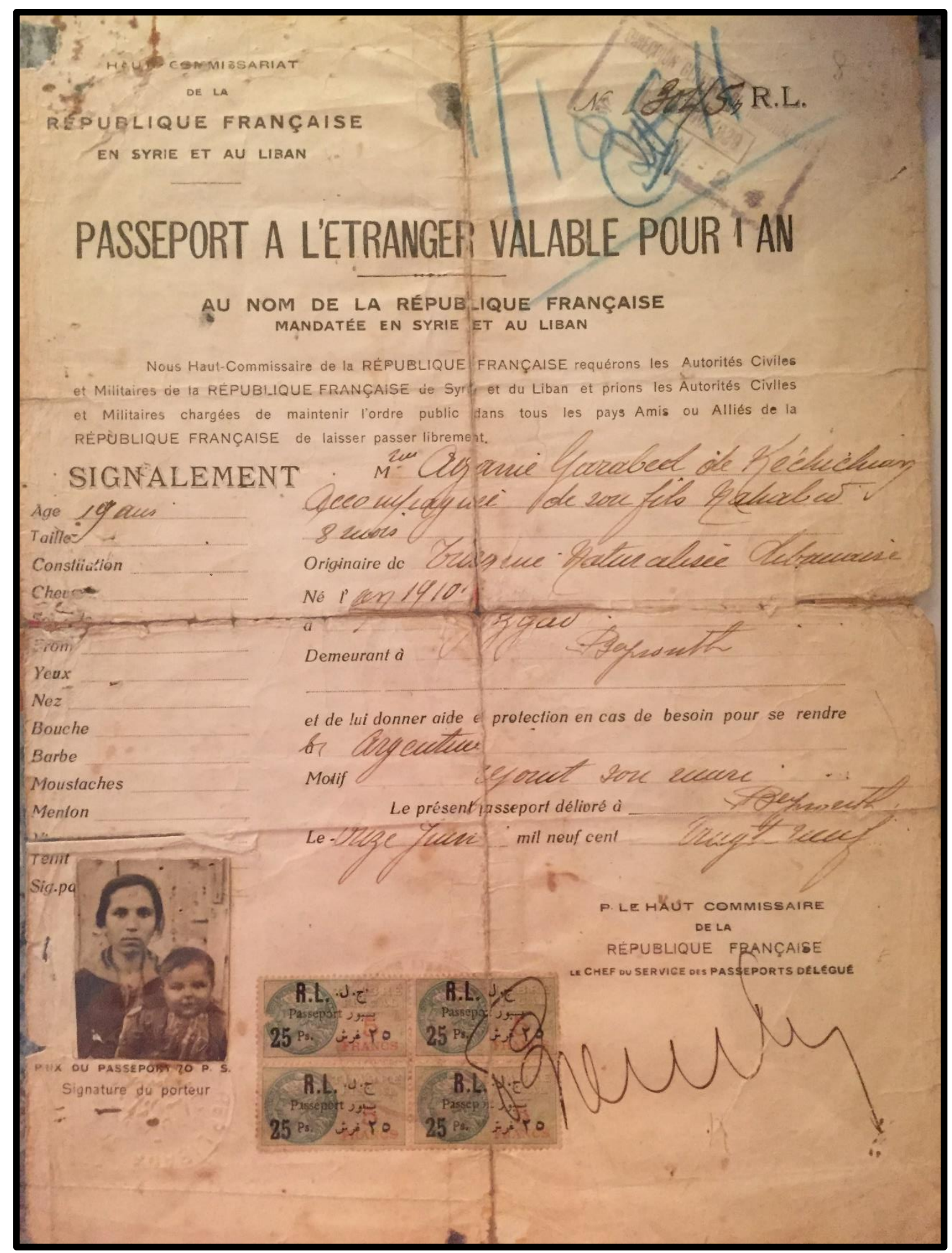


Llegaron a la Argentina, él con 28 años y ella con 19. ${ }^{14}$ Se instalaron en Valentín Alsina, Lanús, Provincia de Buenos Aires, donde ya había una comunidad de armenios establecidos y con instituciones en funcionamiento cada vez más consolidadas. ${ }^{15}$ Tuvieron 8 hijos más. Mi papá fue el menor de ellos.

${ }^{14}$ En las fuentes migratorias argentinas no se desagregan como súbditos otomanos a los armenios. Muchos, a su vez, entraron como persas, sirios, libaneses, rusos, griegos e increíblemente como armenios los que portaban pasaportes Nansen. "Estos pasaportes fueron creados en 1921 por el noruego Fritdjof Nansen para solucionar el problema de los rusos blancos, griegos y armenios que habían quedado sin la protección de su estado y sin documentación, implicaban la prohibición de regresar y los otorgó la Sociedad de las Naciones." Los primeros trabajos publicados acerca de estos datos fueron realizados por Narciso Binayán Carmona, "Entre el pasado y el futuro. Los armenios en la Argentina. Talleres Gráficos Conforti. Buenos Aires. 1996 y por Nélida Bouldgurdjian-Toufeksián, en "Los armenios en Buenos Aires. La reconstrucción de la identidad (1900/1950)”. Agencia Periodística, Diario del Viajero. Buenos Aires. 1997.

15 A partir de algunas entrevistas realizadas en el año 2002 y lectura de distinta bibliografía al respecto puedo agregar que hacia fines de la década del 30 estaban radicados en la ciudad de Buenos Aires y el conurbano alrededor de 20.000 armenios. Hubo significativos asentamientos en Córdoba, los alrededores de La Plata (especialmente Berisso), y también en Montevideo. En la localidad de Valentín Alsina el acceso a la propiedad presentaba grandes facilidades, este es el motivo por el cual un número significativo de armenios decide instalarse allí. Las instituciones fundadas fueron: La escuela Jachikian (1929), en la calle Murguiondo al 2100 (actualmente 232) llamada así en honor a Yervant Jachikian, su benefactor, donde funcionó también la iglesia Surp Shushan o Santa Susana (actualmente Surp Hagop o San Jacobo) y luego la escuela Jrimian (1930), en la calle Yatay al 400 (actualmente en Jean Jaures 3111). Jrimian es el único colegio armenio en la actualidad en Valentin Alsina y está abierto a la comunidad desde hace 2 décadas aproximadamente. La iglesia Surp Shushan (Santa Susana, 1929) fue edificada con la colaboración de los vecinos. En 1960 fue reconstruida por los hermanos Dikran y Eduardo Murekian y, en memoria de su padre, se llamó Surp Hagop (San Jacobo). En 1991 Héctor, Edgardo y Alejandro Murekian la refaccionaron en su totalidad, agregándole un baptisterio, una cúpula cónica al campanario, un hall de entrada y un campanario inspirado en la arquitectura armenia. En 1996, las pinturas del templo que pertenecían a Bagdasar Aivazyan fueron restauradas por la artista Mané Sarafian. Además de las escuelas y la iglesia se crearon filiales locales de algunas de las instituciones comunitarias: la Unión General armenia de Cultura Física, la Sociedad de Damas armenias de Benficencia (HOM), la Unión Juventud Armenia, y la filial Zavarian de la Asociación Cultural Armenia. 
¿Cómo llegaron de Yozgat a Beyrouth? Parte de la ruta de los armenios de Yozgat a partir de 1915 está documentada por Taner Akçam. Tiene relevancia el hecho de que sea un historiador turco exiliado en Estados Unidos, ${ }^{16}$ el traductor y promotor de dar a conocer los intentos que los propios otomanos consideraron juzgar y que luego manipularon en función de tergiversar la historia, borrarla y negarla.

Hay fuentes que conducen a la hipótesis de Akçam sobre el plan sistemático para eliminar un porcentaje de armenios dentro del Imperio Otomano durante la crisis del Otomanismo a principios del s. XIX. Es por eso que su investigación nos muestra cómo al término de la Primera Guerra Mundial, se monta un escenario jurídico de infructuosos resultados, pero revelador en términos de pruebas. Se trata de los intentos de juzgamiento que hubo por parte de varios gobernantes otomanos de posguerra a partir de una serie de documentos oficiales que se citaron en los procesos. ${ }^{17}$ (Sin dejar de mencionar que hubo intentos de juzgar a los criminales - tanto en Paris como en Estambul - por parte de las fuerzas de ocupación británicas. $)^{18}$

\footnotetext{
16 "En febrero de 2009, en un ataque contra la organización terrorista ultranacionalista Ergenekon, cuyos miembros se creía que tenían vínculos cercanos con la burocracia militar y estatal, la policía confiscó un documento de "Traidores a la Seguridad Nacional". En esta "lista negra" se encontraban los nombres de Hrant Dink, el periodista armenio de Estambul asesinado en 2007, del Premio Nobel Orhan Pamuk; y el de este autor". Testimoniado por Taner Akçam en sus publicaciones.
}

17 "Estas cortes, cuyos interrogatorios de instrucción comenzaron en noviembre de 1918, iniciaron sus audiencias en febrero del año siguiente y continuaron hasta 1922. Al final, fueron levantadas a causa de la presión del movimiento Nacionalista Turco, y porque los juicios ya no se percibían como garantía de ventaja alguna para el nuevo gobierno nacionalista, especialmente después de que se refrendara el Tratado de Sèvres y comenzara la partición del Imperio". En Akçam, Taner "Un acto vergonzoso. El genocidio armenio y la cuestión de la responsabilidad turca”. Bs. As. Colihue.2010.

18 "En la declaración de los Aliados, del 24 de mayo de 1915, fue usado por primera vez el concepto de "crímenes contra la humanidad". Este precedente vino a formar el marco legal y el cimiento de los juicios de Núremberg, en 1946. Está mencionado, además, en el preámbulo de la Convención de Prevención y Castigo para los Crímenes del genocidio de las Naciones Unidas, que fue adoptado el 9 de diciembre de 1948 y, por lo tanto, se convirtió en una norma legal internacional”. En Akçam, Taner Op. Cit. 
Uno de esas cortes marciales se realizó en Yozgat:

'Se afirma que además de los alrededores de Bogazlayan había comenzado un "levantamiento" en la región de Akdagmadeni, ambos dentro del distrito provincial de Yozgat. En un cable del 22 de julio de 1915. '19

En la actualidad la bibliografía turca, apoyada en la maquinaria propagandística que desarrollan desde aquellos tiempos, repite y reedita el hecho de los "levantamientos de Yozgat" como la causa de las deportaciones de armenios, que se muestran en el mapa del genocidio armenio. ${ }^{20}$

"En otro telegrama cuya lectura se realizó en el mismo juicio de Yozgat - y en especial durante la audiencia del 22 de febrero de 1919 - el comandante local en Bogazliyan informó que Kemal había organizado la matanza de 1500 armenios. Luego, el juez dio lectura de uno de los telegramas de la cadena de mando militar, que Talaat menciona en los cables del 9 de agosto de 1915. El día siguiente la prensa citó ese telegrama en el que se informa la matanza de 3160 armenios ".21

19 Akçam, Taner "El crimen de Lesa Humanidad de los Jóvenes Turcos" El genocidio armenio y la limpieza étnica en el Imperio Otomano”. Buenos Aires, Eduntref Prometeo, 2016.

20 "Los argumentos que afirmaron la existencia de una revuelta armenia mencionados en los documentos anteriores no tienen sustento en la realidad, sino que fueron falsificados de manera deliberada. En noviembre de 1918, la Comisión Investigadora de Delitos, creada para investigar los delitos cometidos durante la guerra sufridos por los armenios, obtuvo un conjunto de cables, enviados durante el mandato del gobierno unionista, que demuestran con claridad que la información de aquellos documentos es errada. La lectura de los cables quedó registrada en las sesiones del juicio de Yozgat que comenzó en febrero de 1919. El tema se mencionó el 8 de febrero durante la segunda sesión del juicio”. En Akçam, Taner. Op. Cit.

21 Akçam, Taner. Op. Cit 
Estos procesos se enmarcan también en otro hecho errático: el Tratado de Sèvres, ${ }^{22}$ que permitía los juzgamientos a los perpetradores de los delitos cometidos contra el pueblo armenio - dentro del Imperio Otomano - el cual nunca entró en vigencia.

A pesar de no tener registros de testimonios en estas cortes, los cables y telegramas presentados contribuyen a dimensionar el silencio de las víctimas no como un pacto, como puede considerarse al silencio de los perpetradores, sino como la posibilidad de sobrevivir.

\footnotetext{
${ }^{22}$ Fue un Tratado de Paz firmado entre los Aliados, salvo EEUU, Rusia y el Imperio Otomano. En cuanto se vaya presentando la línea cartográfica se podrá corroborar el conflicto por los límites. En ese Tratado, con respecto a Armenia no sólo se hablaba de los juzgamientos a los culpables de los crímenes sino también del territorio armenio hacia occidente.
} 




Período entreguerras / Turquía 1918-1945. Kinder, H. Hilgelmann, W. Atlas histórico mundial. Tomo II. De la Revolución Francesa a nuestros días. Madrid, Istmo, XVIII edición 1996. 


\section{Lengua y Memoria. El borramiento.}

'La "visibilidad" y el reconocimiento de una memoria dependen también de la fuerza de quienes la llevan. Dicho de otro modo, hay memorias "fuertes" y memorias "débiles". En Turquía, la memoria Armenia sigue estando prohibida y es reprimida.

(...). Se perpetúa como recuerdo de una comunidad de vencidos, estigmatizada o abiertamente criminalizada por el discurso dominante. La memoria Armenia permanece débil, puesto que quienes la niegan disponen de un Estado reconocido en el plano internacional, al que los demás Estados prefieren a menudo no recordarle el pasado por conveniencia económica o geopolitica.' 23

En la diáspora y en la Armenia Soviética se elaboró la historia y la memoria del genocidio. Hay allí una controversia respecto del vínculo con el territorio de la Armenia histórica occidental que describiré más adelante, pero ¿qué pasó en Turquía con la historia, el territorio y la memoria?

"La reforma del alfabeto de 1928, que cambió la escritura turca en árabe por las letras latinas, sirvió para agravar el problema. (...). En este sentido, se vuelve claro por qué la sociedad turca ha destinado el Genocidio Armenio al olvido". ${ }^{24}$

La multiplicidad de factores que negaron la construcción de la memoria tuvo origen en el borramiento no sólo por parte del Estado Turco sino también por un mecanismo de supervivencia con distintas características entre algunos sobrevivientes.

\footnotetext{
${ }^{23}$ Traverso, Enzo. Memorias "fuertes" y memorias "débiles" en Historia Reciente Perspectivas y Desafíos para un campo en construcción, Marina Blanco y Florencia Levin Comp. Buenos Aires, Paidós, 2007.

${ }^{24}$ Akçam, Taner (2010) Un acto vergonzoso. El genocidio armenio y la cuestión de la responsabilidad turca. Bs. As. Colihue.
} 
"Los armenios más conscientes también saben que su historia no está hecha sólo de horribles recuerdos y que una cultura que se alimentara solamente de un genocidio rápidamente se convertiría en una cultura muerta." 25

Taner Akçam estuvo preso en Turquía por su actividad como dirigente universitario de izquierda, logró fugarse, y cuando emprendió una nueva carrera académica investigó el Genocidio Armenio. Akçam vive en EEUU, pero desde 1999 está autorizado a visitar su país natal. En su libro "Un acto vergonzoso" documenta lo que encuentra de modo “casual”. En Turquía no habían quedado huellas, ni Historia.

"Durante la reforma del siglo XIX, cuando parecía que el sistema de millet todavía podía adaptarse a las exigencias del imperio, la ideología dominante era el otomanismo, cuyos principios estaban encarnados en la constitución de reforma de Midhat Pasha. ¿Cuáles eran sus objetivos? Por un lado, mantener la integridad del imperio al otorgar una mayor autonomía a las millet minoritarias e introducir ciertas reformas y derechos liberales que regirían por igual para todos los otomanos, sin importar su religión y nacionalidad de origen. La Constitución fue escrita con la participación de intelectuales armenios." ${ }^{26}$ El Tratado de Sèvres firmado en 1918, fue reemplazado por el de Lausana de 1920 incumpliendo los límites del reconocimiento del territorio armenio y los juzgamientos, profundizando la violencia.

“¿Qué ocurrió con aquellos niños armenios escondidos en hogares musulmanes con el fin de resguardar su seguridad en vez de someterlos a la asimilación? El gobierno estaba convencido de que dichos niños preservarían la identidad armenia por lo que, en el futuro, constituirian una fuente de conflictos. Acerca del modo de abordar este grave problema, el comandante del tercer Ejército Mahmud Kamil pasa notificó a las

\footnotetext{
25 Vidal Naquet, Pierre. "By way of A Preface and By the Power of One Word", en Gerard Libaridian (ed.) A Crime of Silence: The Armenian Genocide, Londres, Zed Books, 1985, en Op. cit

${ }^{26}$ Akcam aclara que luego, bajo el gobierno de Abdul Hamid, el Otomanismo tuvo que pasar a la clandestinidad donde encontró sus defensores entre minorías tales como los Dashnaks armenios y el ala liberal del movimiento de Jóvenes Turcos conducido por el príncipe Sabahaddin.
} 
provincias "Se comunica la orden de ejecutar a aquellos que escondan a armenios que deben ser deportados al interior. El castigo (por ello) no rige sobre quienes albergan a mujeres y niños... que les fueron encargados de manera oficial por el actual gobierno. Sin embargo, aquellos que escondan a armenios de cualquier sexo y religión en sus hogares sin el conocimiento del gobierno y en cuya casa se encuentren niñas o mujeres sin haber contraído matrimonio de manera oficial recibirán el castigo antes mencionado. $" 27$

Negación, borramiento, ocultamiento, tratados y destratados. Aquí, en Buenos Aires, ¿Cómo afectó este mecanismo de supervivencia? Una de las particularidades con las que me encontré al estudiar a la comunidad armenia de Valentín Alsina, fue el hecho de saber a través de una entrevista al profesor Sergio Kniasian ${ }^{28}$ investigador, docente y vecino del barrio, que el Colegio armenio Jrimian de Valentín Alsina mostró desde su fundación en 1930, las consecuencias del borramiento y el conflicto con la lengua de aquellos sobrevivientes. En un pasaje de la entrevista dice; "Acá lo primero que hicieron los que vinieron fue fundar escuelas. En un trabajo que hice justamente acá en Valentín Alsina, la Comisión Directiva, ninguno sabía hablar ni leer en armenio y fundaron una escuela (...) En la mentalidad de esta gente (los armenios) estaba el estudio como algo prioritario, tanto para mantener la base de la nacionalidad como para el progreso de la persona. Es muy, pero muy llamativo que, en general, en las comisiones fundadoras de las escuelas, casi nadie haya podido ir a una escuela. Es más, algunos ni siquiera sabían el idioma armenio. En las escuelas que fundaron ellos mismos aprendieron el idioma." Este nexo complejo entre lengua y territorio es la base para la escucha y alianza con las tierras ancestrales.

\footnotetext{
${ }^{27}$ Akçam, Taner Op. Cit.

${ }^{28}$ Entrevista realizada a Sergio Kniasian, en el año 2002, que forma parte de mi archivo personal y fue utilizada para mis primeros trabajos de investigación sobre la comunidad armenia de Buenos Aires.
} 


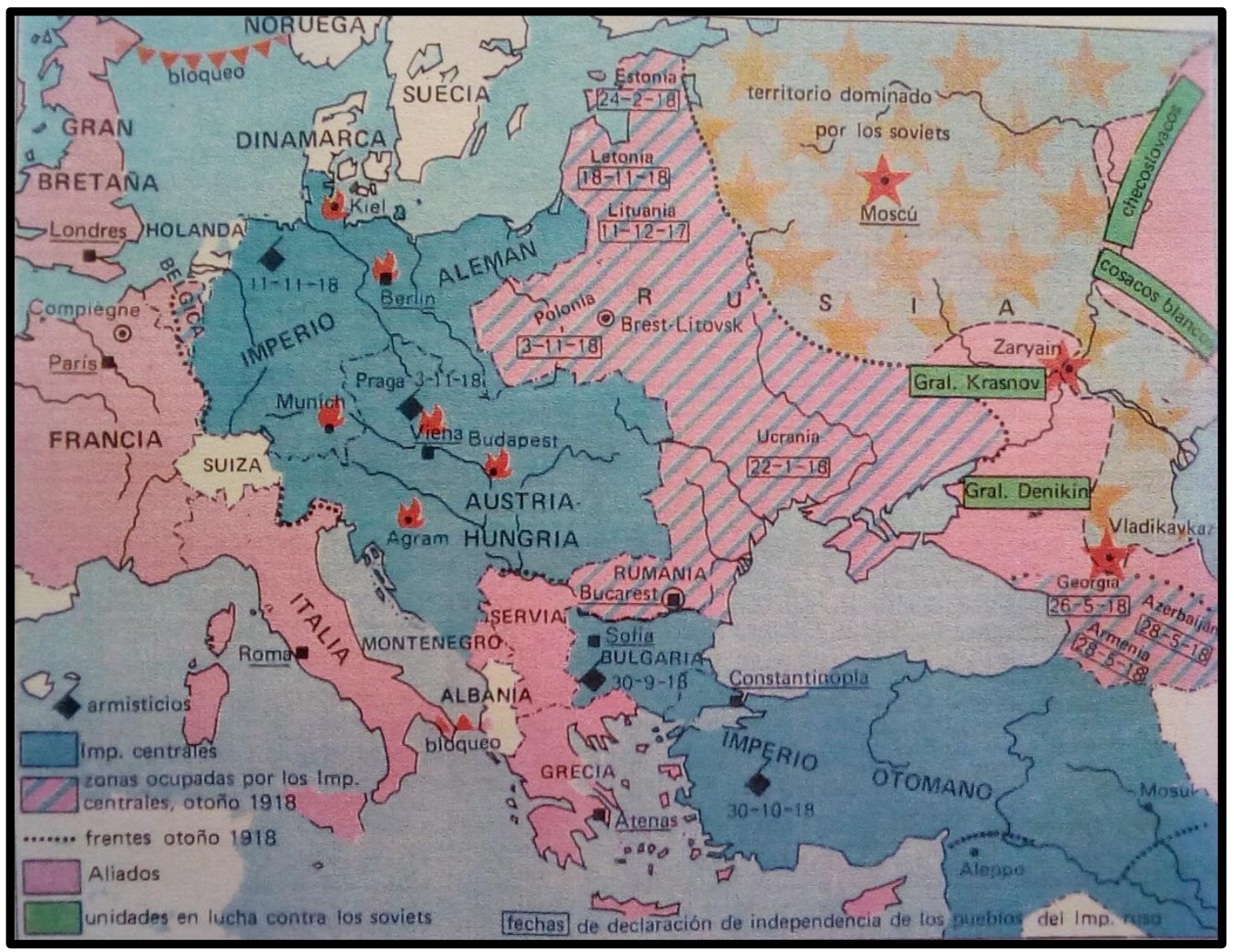

Primera Guerra Mundial. El fin de las hostilidades 1918. Kinder, H. Hilgelmann, W. Atlas histórico mundial. Tomo II. De la Revolución Francesa a nuestros días. Madrid, Istmo, XVIII edición 1996. 


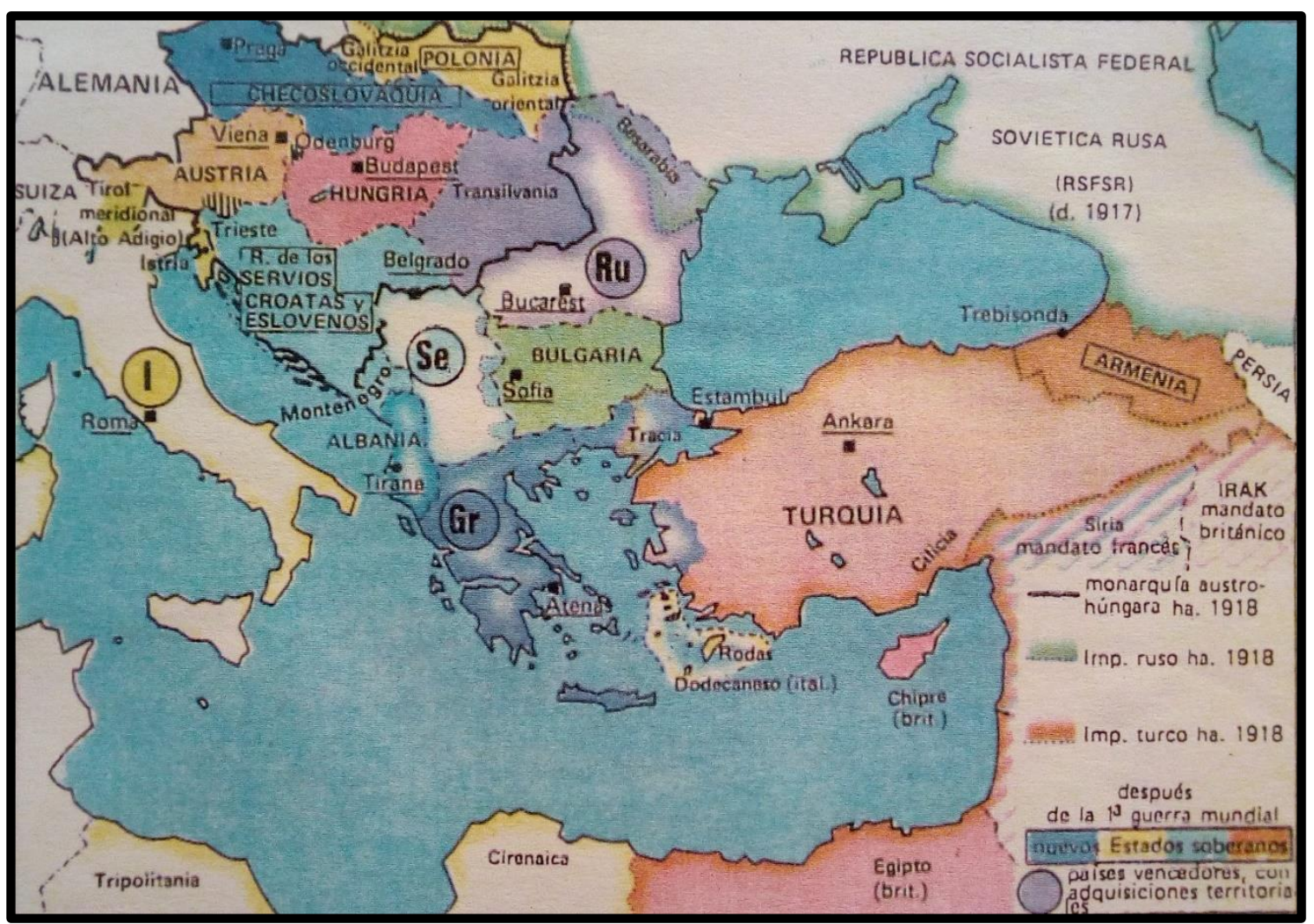

Primera Guerra Mundial / Tratados de Paz (1918-1920) Europa sudoriental y Oriente Medio 1918 Kinder, H. Hilgelmann, W. Atlas histórico mundial. Tomo II. De la Revolución Francesa a nuestros días. Madrid, Istmo, XVIII edición 1996. 


\section{SEGUNDO MOMENTO}

\section{La declaración del acusado que se convirtió en testimonio de sobreviviente. Berlín} 1921.

“Sólo la reincorporación a la comunidad jurídica por medio del derecho penal puede devolver la condición de persona al genocida y, por ende, darle el poder jurídico la base ética que le permite imponer límites y, en consecuencia, deslegitimar la acción de quien quiera masacrarlo. No es una mera teoría, es un hecho verificable y el proceso de

Berlín es una acabada prueba de ello. Las actas de ese proceso, a noventa años de distancia, cobran especial actualidad. Los jurados alemanes de 1921 nunca pudieron sospechar que con su voto absolutorio unánime estaban proveyendo al futuro lejano un argumento de legitimación de las pulsiones internacionalizantes del derecho penal. Muchas veces lanzamos semillas al viento sin saberlo." 29

La indiferencia, a principios del siglo pasado, hacia delitos ejercidos por la mano del Estado se transformó en la base del negacionismo. Sin embargo, pensar en la anacronía del concepto de justicia por mano propia y de los límites del derecho en materia de delitos de lesa humanidad nos hace valorar el devenir del término genocidio.

La siguiente escena jurídica ${ }^{30}$ pertenece al juicio contra Sohomón Tehlirian realizado en Berlín en 1921. Tehlirian formó parte de la Operación Némesis, un grupo que actuó en Europa y Asia principalmente, que ajustició a los jerarcas turcos que gozaron de impunidad luego del juicio en ausencia que se les realizara por los crímenes cometidos durante la Primera Guerra Mundial.

\footnotetext{
${ }^{29}$ Zaffaroni, Raúl Eugenio, Estudio Preliminar en "Un proceso Histórico” Absolución al ejecutor del genocida turco Talaat Pasha, Buenos Aires, EDIAR, 2012

30 Transcripción de un fragmento del Juicio contra Sohomón Tehlirian. Proceso C.J.22/21. Berlín 2 y 3 de junio de 1921 en “Un Proceso Histórico”. Bs. As. Ediar, 2012-
} 
Defensor Von Gordon - El 15 de marzo usted vio a Talaat salir de la casa, tomó la pistola, se puso el sombrero y luego de bajar por las escaleras salió a la calle. En ese instante, por lo que puedo juzgar, Talaat Pashá habría avanzado bastante sobre la calle Gnezelberg.

Acusado - Ya le dije, corrí para alcanzarlo.

Defensor Von Gordon - En ese caso usted habría pasado la franja verde de la calle Harttenberg ¿Estaba usted delante de él?

Presidente - Dé una vez más una explicación al respecto.

Acusado - Yo me adelanté por el costado de Talaat Pashá, aguardé y, cuando pasó por mi lado disparé.

Presidente - En cierta medida eso fue una imprudencia, Talaat Pashá podía verlo y sospechar que planeaba algo en su contra. Esa fue una terrible imprudencia. ¿No se le acercó por la espalda?

Acusado - No pensé semejante cosa.

Presidente - Existen dos posibilidades: ¿pasó usted por el costado de Talaat, adelantándose, o se le acercó por atrás? Hasta ahora no sabemos claramente si Talaat pasó por su costado.

Defensor Von Gordon - De todo lo dicho llego a la conclusión de que Talaat ha pasado por su costado. El acusado siempre se ha expresado en ese sentido. ¿Vio el rostro de Talaat?

Acusado - Si, mientras caminaba por el otro lado antes de pasar a la acera de Talaat.

Presidente - Veremos qué dirán los testigos al respecto.

Fiscal Kolnik - Hace un rato el acusado contestó la pregunta de uno de los Defensores diciendo que sabía que Talaat Pashá había sido condenado a muerte en Constantinopla. Es verdad, hubo tal condena, pero debo recalcar que fue dictada cuando en Constantinopla las riendas del poder se hallaban en manos de otro gobierno, pues Turquía yacía vencida y Constantinopla estaba bajo los cañones navales británicos. Dejo a la consideración del tribunal la apreciación del valor de esa condena de muerte y ruego que se le formule al acusado la siguiente pregunta: dijo que había encontrado el cadáver de su hermano, ¿lo enterró?

Acusado - No. 
¿Por qué retomar esa pregunta? ¿Por qué no pudo enterrar a su hermano?

El inicio de su declaración se transforma en la voz de las víctimas del genocidio armenio, aunque en ese momento el delito no estaba tipificado. ${ }^{31}$

Presidente - Sería aconsejable que los acontecimientos preliminares al hecho que se juzga sean estudiados junto con la investigación del legajo personal del acusado.

Fiscal Kolnik - (Luego de consultar con el Tribunal) Deseamos que el acusado nos explique detalladamente la forma en que tuvieron lugar las matanzas y los padecimientos que ha sufrido su familia, que el acusado nos narre por partes y luego se traduzca su relato.

Acusado - Al empezar la guerra de 1914 los armenios fueron movilizados. En mayo de 1915 corrió la noticia de la clausura de las escuelas y de la deportación en grupos de los maestros y notables de la ciudad.

Presidente - ¿Los reunían en lugares fijos o en campos de concentración?

Acusado - No lo sé, los concentraban y los ponían en marcha. Yo tenía miedo y no quería salir de mi casa. Ya habían sido deportados varios contingentes, cuando llegó la noticia de su aniquilación. Luego nos enteramos por un telegrama que de esos deportados sólo uno había salvado su vida; Mardirossian. A principios de junio llegó la orden de que la población abandone la ciudad. Se dijo que el dinero y los objetos de valor podían ser

${ }^{31}$ La tipificación del delito de Genocidio tiene su origen en el trabajo del jurista judío polaco Rafael Lemkin. "En 1921, a los 21 años de edad, mientras estudiaba lingüistica en la Universidad de Lvov leyó, en un diario local, la noticia sobre el asesinato de Talaat Pasha a manos de un armenio que sobrevivió a la matanza de su familia. Esto intrigó a Lemkin, quien comentó el caso con uno de sus profesores. Lemkin preguntó por qué los armenios no habian hecho arrestar a Talaat por la masacre. El profesor le contestó que no habia ninguna ley por la que pudiera ser arrestado (...) Sohomón Tehlirian, el asesino armenio, fue aprehendido enseguida. Mientras los transeúntes lo golpeaban con puños y llaves, gritó en su mal alemán: "Yo extranjero, yo extranjero. Esto no lastimar a Alemania...Nada que ver con ustedes". Era justicia nacional en un escenario internacional. (...) Para entonces, la soberanía se tenía como un concepto sacrosanto que estaba por encima de los derechos individuales a la justicia. “

http://www.raoulwallenberg.net/es/holocausto/articulos-65/genocidio/raphael-lemkin-padre 
entregados a las autoridades para su custodia. Tres días después, por la mañana temprano, la población fue sacada de la ciudad.

Presidente - ¿En grandes grupos?

Acusado - Cuando llegó la orden de abandonar la ciudad, el pueblo fue inmediatamente concentrado y dividido en grupos en las afueras; luego, en caravanas, se los puso en marcha.

Presidente - ¿Habia permiso para llevarse las pertenencias personales?

Acusado - Era imposible llevarse todo, por falta de caballos, etcétera; sólo se podía llevar cargas personalmente.

Presidente - ¿Tenían ustedes carros para llevar sus cosas?

Acusado - Antes teníamos un caballo, pero al comienzo de la guerra fue requisado. Luego compramos un burro.

Presidente - ¿Y ese burro transportaría todas sus pertenencias? ¿No tenían ningún carro?

Acusado - Teníamos un carro tirado por bueyes.

Presidente - ¿Cuántos días caminaron?

Acusado - No sé; mis padres fueron asesinados el mismo día que abandonamos la ciudad.

Presidente - ¿Adónde los llevaban?

Acusado - Hacia el sur.

Presidente - ¿Quién custodiaba la caravana?

Acusado - Gendarmes, jinetes y soldados.

Presidente - ¿En gran número?

Acusado - Por ambos lados, a lo largo del camino.

Presidente - ¿Por delante y por detrás?

Acusado -Por ambos lados.

Presidente - ¿Vigilando para que nadie se separe?

Acusado - Sí.

Presidente - ¿Cómo tuvo lugar la muerte de sus padres y hermanos?

Acusado - Cuando el grupo se alejó un poco de la ciudad, nos hicieron detener y los gendarmes empezaron a saquear para apropiarse del dinero y de los objetos de valor. Presidente - ¿Así que los propios soldados se dedicaban al pillaje de los deportados? Acusado - Sí. 
Presidente - ¿Y qué argumento se esgrimía para justificar semejante proceder?

Acusado - Respondían en tono irónico. Nadie decía nada, pero todo el mundo sabía que lo inexplicable era posible en las entrañas de Asia.

Presidente - ¿De modo que tuvieron lugar sucesos semejantes sin que se explicaran sus causas?

Acusado - Así es.

Presidente - ¿Con otras poblaciones también?

Acusado - Los turcos actuaron así con todos, pero especialmente con los armenios.

Presidente - ¿Cómo fueron asesinados sus padres?

Acusado - Durante el saqueo, desde el frente de la caravana se abrió fuego sobre nosotros. En ese instante uno de los gendarmes llevó a mi hermana arrastrándola. Mi madre comenzó a gritar: “'Que me quede ciega!”. Yo no quiero recordar aquel día, no quiero que me hagan recordar...prefiero morir antes que recordar aquel día nefasto...

Presidente - Pero deseo llamarle la atención de que para el tribunal es muy importante oír por su boca la narración de estos hechos, pues usted es el único que puede informar al respecto. trate de dominarse y concentrarse.

Acusado - Yo no puedo narrar todo eso porque lo revivo cada vez. Me golpearon. Se llevaron a todos arrastrándolos. Luego vi cómo le partieron de un hachazo la cabeza a mi hermano...

Presidente - ¿Su hermana pudo volver?

Acusado - Mi hermana fue arrastrada y violada...

Presidente - ¿Volvió?

Acusado - No.

Presidente - ¿Quién le partió de un hachazo la cabeza a su hermano?

Acusado - Apenas los gendarmes habían empezado la masacre, se les unió la turba; en ese instante mataron a mi hermano...mientras caía mi madre...

Presidente - ¿Cuál fue la causa de su caída?

Acusado - no sé, un balazo o alguna otra cosa..

Presidente - ¿Dónde estaba su padre?

Acusado - No vi a mi padre, él estaba adelante, pero allí también se mataba...

Presidente - ¿Qué hizo usted? 
Acusado - Fue entonces cuando recibí un golpe en la cabeza y caí; después ya no recuerdo nada más...

Así se produjo el momento en el cual un tribunal pudo escuchar el testimonio de un sobreviviente a través del interrogatorio a un homicida. El tribunal no pudo disociar, separar, desvincular.

El hecho de haber dejado libres a los jerarcas turcos condenados exhibió un doble "crimen" por parte de la comunidad internacional. La justicia se exhibió fuera de su alcance y por eso Tehlirian fue absuelto.

¿Qué ocurrió con aquellos que habiendo visto masacrar a sus familias pensaron en hacer justicia por mano propia? ¿Es constructivo hacernos esta pregunta? ¿Cómo dibujar los límites cuando el derecho penal internacional no ha podido? ¿Qué pasó con tantos cuerpos que no pudieron ser enterrados por sus familiares? ¿Por qué no hay más voces de sobrevivientes en los tribunales? 




Las Nacionalidades / Asia occidental (1736-1914) Kinder, H. Hilgelmann, W. Atlas histórico mundial.

Tomo II. De la Revolución Francesa a nuestros días. Madrid, Istmo, XVIII edición 1996. 


\section{Identidad y conflicto, la tolerancia y el respeto.}

"La coexistencia de hablantes de armenio y turco generó una polémica curiosa, aunque comprensible en el contexto de la mentalidad del sobreviviente. En mayo de

1924 el Centro Colonial Armenio resolvió conmemorar el sexto aniversario de la primera independencia de la república de Armenia, para lo cual realizó una asamblea general con los representantes de las distintas entidades. Como se desprende del acta,

parte de los asambleístas no estuvo de acuerdo en que en un acto patriótico de esa índole el "idioma del amo" tuviera lugar, por lo que debió recurrirse a una solución de emergencia " 32

El momento que se enuncia cada 24 de abril apelando al respeto y tolerancia entre los pueblos es un enunciado que no nos aleja del odio.

El 18 de mayo de 2017 concurrí al Palais de Glace a la presentación del libro Infieles ${ }^{33}$ de Ana Arzoumanian. Sentí luego que tenía que seguir dialogando con ella respecto de este tema tan perturbador...y sobre lo que sigue sin nombrarse entre turcos y armenios, y a pocos días de leerlo, le escribí.

Ana querida:

Dos veces leí tu libro, sentí al leerlo algo extraño, como si no pudiera fluir, me preguntaba, ¿qué me molesta? Me daba cuenta de que necesitaba tomar un ritmo diferente, que me había acostumbrado a leer "de una determinada manera" y que en esta oportunidad no me servía.

\footnotetext{
${ }^{32}$ Matiossian, Vartan. "Pasado sin retorno, futuro que espera: los armenios en la Argentina, ayer y hoy", Montevideo: Asociación Cultural Uruguay-Armenia, 2011.

${ }^{33}$ Arzoumanian, Ana "Infieles", Buenos Aires, Libros del Zorzal, 2017. Ver presentación en https://www.youtube.com/watch?v=cFwojdcTyVY
} 
Por eso lo terminé y lo empecé nuevamente, me dije "lo leí muy mal" ..., en los momentos muy explícitos me sentía incómoda y ¿por qué?... la pornografía claramente me perturbaba más de la cuenta.

Estaba leyendo sobre la apropiación del territorio. Sobre el derrame de sangre en ese territorio.

Eso sentía mientras leía, una sucesión de imágenes pornográficas muy enloquecedoras, aún más que con la pornografía de las masacres de la que alguna vez hablamos...

La segunda vez traté de buscar algún tipo de desenlace, como si no quisiera entender que, en realidad, no importaba tal desenlace, que importaba leer y sentir el conflicto. Aquí, por ejemplo:

Tengo una mala noticia.

¿En qué idioma? ¿Con qué letras la escribiré?

Mejor no la escribo.

Mejor la digo. La digo en voz alta o la susurro. La voy diciendo a quien pueda escuchar:

a la mujer violada no la mataron.

La mujer violada tuvo su hijo, su cría.

Ella no mató a su niño.

A ella, no la mataron.

La mujer violada es mi abuela.

Tengo una mala noticia: su hijo

no murió,

y todavía vive

entre ellos.

Me detenía, retomaba, seguía el ritmo y agregaba preguntas ¿es una mala noticia? que él viva ¿es una mala noticia? ¿Quiere ser encontrado? ¿es un desaparecido?

¿Qué es la verdad? 
La imprenta, una invención cristiana.

Libros cómplices.

La mecánica de reproducir textos e imágenes sobre papel: aplicar una tinta oleosa sobre una pieza metálica para transferirla al papel por presión.

EI hijo de mi abuela, una tinta oleosa.

Buscaré la presión si no encuentro el papel. La prensa, la argolla, el pilar.

¿En qué relato después de esto creerán?

¡La mala noticia es la verdad!!!??? Mezcla de euforia y miedo Ese hijo como un relato, como una verdad, ese hijo es la verdad aunque no esté en ningún papel o tal vez un palimpsesto... - recuerdo a las disciplinas que auxilian a la historia -, me voy por ahí mentalmente y vuelvo a la búsqueda de esa verdad, me enrosco con eso y continúo

Llamar a las cosas por su nombre.

Busco al hijo de mi abuela. El hijo de mi abuela habrá cambiado su apellido.

¿Cómo será el hijo de mi abuela sí, para seguir vivo, tuvo que destruir parte de sí?

Vive, porque es verdad, realidad, existe, aunque haya preguntas en torno a su existencia y esas son las preguntas de la historia pienso, de nuevo, la historia, pero otra vez el ritmo de mi lectura, mi problema, me llevás a otra parte y me preocupa ser tan literal

Una hembra no está embarazada o da a luz sin que Él lo sepa.

El libro trata de causar un efecto, no de informar. Un ángel que desciende con un abrazo que mata al hombre, a su pasado.

Lo ensoñado hace eco en el cuerpo. Buscar en el hijo de la abuela a la Eva mitocondrial. Buscar en el hijo a la madre. Una herencia que no muestre que la elegancia de la espada, que la daga, no pudo resistir el brazo envenenado de la abuela.

Quien te detesta carecerá de hijos varones. 
Y ningún soldado contestaba una pregunta que flotaba en el aire: ¿podremos considerarnos hermanos cuando acabe la guerra?

¿Lo ves? me detengo en estos pasajes... insisto. Y resuena el Corán, lo recuerdo cantado porque estuve allí, en la presentación de este, tu libro, tan bellamente organizada; lectura y canto.

A la abuela le faltaba un mar. Se enterró, como su lengua se enterró entre las piernas del soldado. Por eso ese niño, su hijo, el sin medida, el hijo que succiona los pechos de otra madre, es más turco que un turco. Vive en la desmesura, los extremos.

Vi cómo construiste un nuevo sentido del ser turco, con misceláneas otomanas, o quizás posturcas, posarmenias, posotomanas, posverdades como vengo escuchando últimamente. $\mathrm{Y}$ en esa lucha por la apropiación de los cuerpos que experimentan hasta la transformación, como si quisieras de algún modo, convertir al hijo de esa abuela en un nuevo ejercicio de construir al turco, tal vez al armenio, al otomano.

Yo cierro los ojos sólo ante el roce de su miembro, su miembro que deshace todo resquicio de memoria.

Cuando los abra ya no recordaré quién, dónde.

Me repetiré a mi misma:

esto es lo que se sabe.

Esto es lo que se sabe.

¿En qué relato después de esto creerán?

"La Diáspora arrastra "mitologías nacionales" que no coinciden necesariamente con la narrativa central del gobierno y/o de la población de Armenia. Los reclamos por el Genocidio y la restitución material y territorial, a pesar de su profundo significado histórico y politico, pertenecen a una agenda del pasado, en tanto que el Estado-nación en formación necesita una agenda para el futuro. La debilidad relativa del estado, 
sumada a los brotes de violencia política y a la corrupción endémica, impide que sustituya a la Diáspora como protagonista e imponga su propia narrativa. "34

Para poder escuchar y atravesar la ignominia sin dejar de lado el momento inmediato anterior al genocidio, es necesario tener en cuenta el hecho del borramiento como un trauma no sólo para la diáspora sino también para los armenios que sobrevivieron en Turquía. Sus descendientes y el borramiento allí; descendencia y supervivencia, ADN y territorio.

\footnotetext{
${ }^{34}$ Abcarian, "Amboguous Legacy, p. 216 citado por Vartan Matiossian en "Pasado sin retorno, futuro que espera. Los armenios en la Argentina", Op. Cit.
} 


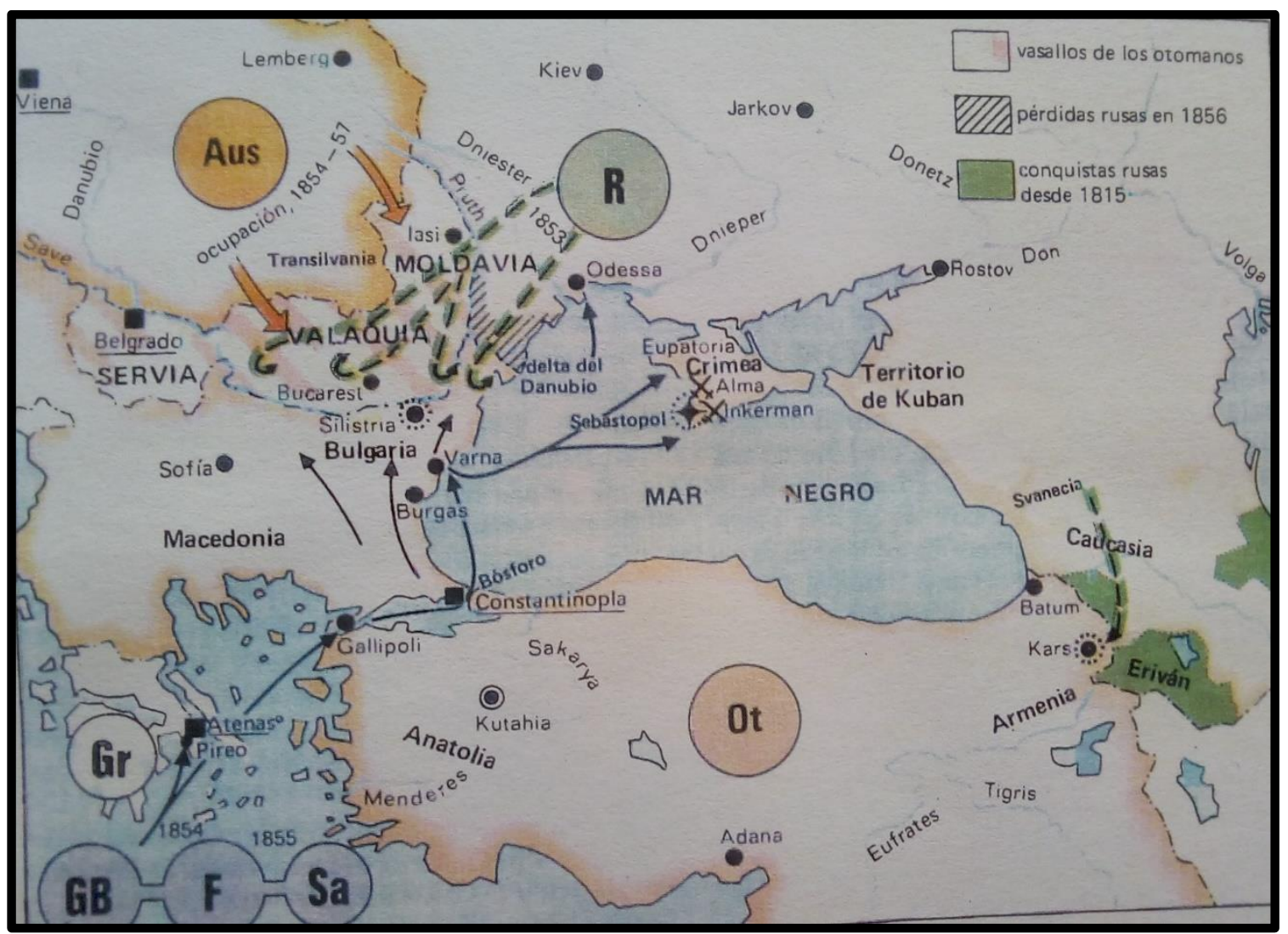

Las Nacionalidades / Rusia (1815-1874) Kinder, H. Hilgelmann, W. Atlas histórico mundial. Tomo II. De la Revolución Francesa a nuestros días. Madrid, Istmo, XVIII edición 1996. 


\section{La diáspora armenia entre la negación y el negacionismo}

Turquía cerró la frontera en 1993 debido al conflicto entre Armenia y Azerbaiyán por el territorio de Nagorno Karabaj. ${ }^{35}$

En el año 2009 con la firma de los Protocolos de Zurich se intentó remediar el bloqueo. No resultó. La Diáspora armenia reaccionó fuertemente contra estos Protocolos. ${ }^{36}$

¿Un genocidio es relevante por lo que sucedió en el pasado o por los sentimientos que despierta en el presente? En el caso de los Estados Unidos, el intento de "conversión ritual de la experiencia del genocidio en un elemento estable de su propia identidad" carece de atractivo para buen aparte de las nuevas generaciones. ${ }^{37}$

Por el otro lado, en el caso argentino, se argumenta, "no les resulta incómodo tratarlo, ni estudiarlo, ni recordarlo porque frente a la ausencia del dolor directo, nace la sed de justicia característica de los jóvenes” 38

El trauma continúa, Ana problematiza la cuestión del odio y lo coloca en un lugar incómodo a nivel vincular entre armenios y turcos complejizando la dinámica de la construcción de la armenidad, nos ayuda a seguir interpelándonos.

"Los sobrevivientes y sus descendientes "se cuentan" como sujetos de la envidia de la barbarie turca. (...). Sujetos de la envidia-odio, estarían retratados en la proposición de

\footnotetext{
35 Guerra de Nagorno Karapagh 1988 - 1994, enclave armenio en Azerbaiyan https://www.infobae.com/2016/05/21/1812752-viaje-la-guerra-olvidada-nagorno-karabaj/

36 Protocolos http://www.lavanguardia.com/internacional/20091010/53802315107/turquia-y-armeniadan-un-paso-historico-para-resolver-su-largo-enfrentamiento.html
}

Reacción de la Diáspora http://www.diarioarmenia.org.ar/los-protocolos-son-pasado-armenia-rompe-elacuerdo-con-turquia/

37 Aram Barceghian, "Un viaje por la misteriosa ruta de nuestra identidad" Sardarabad, 8 de noviembre de 2006 citado por Vartan Matiossian en Pasado sin retorno, futuro que espera. Los armenios en la Argentina.

${ }^{38}$ Matiossian, Vartan Op. Cit. 
Spinoza: "el que imagina que alguien le tiene odio y cree no haberle dado causa alguna de odio, la tendrá a su vez odio". ${ }^{39}$

Armenios en la ex República Socialista Soviética, turcos y armenios en Turquía, la diáspora armenia, turcos y armenios que denuncian el negacionismo, armenios de Artsaj, el ADN y el territorio en todos ellos. Podemos escuchar (nos) y sentir (nos) en territorio.

39 “Ahora bien, si la persona imagina haber sido la causa justa de odio (aquí vale hacer la distinción entre los armenios sobrevivientes del genocidio que llegaron a la Argentina, de aquellos que vinieron al país luego de residir en Turquía. éstos últimos, bajo nombres convertidos, fueron criados y educados según el relato de la "traición" de la minoría armenia al régimen otomano, de la "culpa" en la respuesta revolucionaria); entonces, si imagina que justamente es odiado su afecto será el de la vergüenza (inmigración armenia proveniente de Turquía, luego de haber vivido allí una vez caído el imperio). Demostrando esta proposición, se concluye que el esfuerzo por hacer el mal a aquel que odiamos se llama ira; pero el esfuerzo por devolver el mal que ha sido hecho se denomina venganza. "Ana Arzoumanian Op. Cit 




Expansión del Imperio Otomano 1300-1683 Kinder, H. Hilgelmann, W. Atlas histórico mundial. Tomo I. De los orígenes a la Revolución Francesa. Madrid, Istmo, XVIII edición 1996. 


\section{Coordenadas del regreso.}

"El duelo lleva inscripta la posibilidad de aprehender un modo de desposesión fundamental para lo que soy. Pero antes que contradecir el hecho de mi autonomía, esta posibilidad la reivindica recurriendo a la sociabilidad fundamental de la vida corporal, a los modos por los que estamos desde un principio, y en virtud de ser seres corporales, entregados a otros, más allá de nosotros mismos, implicados en vidas que no son las nuestras. Si en tales ocasiones no siempre sé lo que se apodera de mí, si no siempre sé qué es lo que perdí en otra persona, debe ser que esta esfera de desposesión es precisamente la que expone mi desconocimiento, la huella inconsciente de mi sociabilidad primaria. ¿Puede conducir esta comprensión a una reorientación normativa de la política? Esta situación de duelo - tan dramática para aquellos que, como parte de movimientos sociales, sufrieron innumerables pérdidas - ¿puede proveer una perspectiva desde la cual se pueda empezar a pensar la situación global contemporánea? ${ }^{\prime 40}$

Viajé a Armenia en junio de 2016. Aquel viaje me hizo escuchar el silencio. Exactamente fue el día que contemplé el complejo de Dzitsernagapert, ${ }^{41}$ caminé un largo rato por el Memorial. Caminé desde lejos teniendo en cuenta la distancia entre el ingreso al complejo y el centro del Memorial del genocidio Armenio, en Ereván, capital de Armenia.

40 Butler, Judith. "Vida precaria. el poder del duelo y la violencia" Buenos Aires, Paidós espacios del saber 2009 reimpresión

${ }^{41}$ El Memorial Tsitsernakaberd (Fortaleza de las Golondrinas) está compuesto por una pirámide de 44 metros de altura que representa el renacimiento de la nación armenia; doce estelas agrupadas en un círculo que resguarda, a una profundidad de 1,5 metros, la "llama eterna", signo de duelo; y un muro en el que están inscritos los nombres de los principales pueblos afectados por las masacres perpetradas por el Estado turco. Junto al memorial se encuentra un museo circular subterráneo que expone los hechos ocurridos desde 1915. https://www.cipdh.gob.ar/memorias-situadas/ 
Me detuve frente a la ofrenda floral que el papa Francisco ${ }^{42}$ había dejado minutos antes de que llegara con mi grupo, con quienes compartí ese viaje. Continué por la explanada; era de casi una cuadra de largo y observé todo el complejo. Mi visión llegaba hasta los bloques ubicados en forma de círculo. Me pareció enorme, con el conjunto cerrándose en el círculo y el obelisco esbelto a su lado. Observé la distancia todo el tiempo, la caminé flanqueada a la izquierda por un muro de basalto de 100 metros con inscripciones. Eran inscripciones eran los nombres de los pueblos armenios donde se perpetró el genocidio. Esos lugares se encuentran en la actual Turquía, del lado derecho. Del lado del Ararat, a lo lejos. Se distinguen bien sus dos picos, nieve y niebla.

Dentro del espectro circular de los 12 bloques está la llama eterna que homenajea a los mártires, dejé allí, a sus pies, una flor...

El intento de contrarrestar con la construcción de memoriales el miedo y el riesgo del olvido de los crímenes de lesa humanidad es una problemática que estuve leyendo en los textos de Andreas Huyssen. Antes de llegar a Dzitsernagapert tenía bastante claro que iba a estar en ese lugar, el lugar del "no olvidamos...". Sin embargo, allí reflexioné sobre algo que Huyssen también plantea:

"La memoria siempre es transitoria, notoriamente poco confiable, acosada por el fantasma del olvido, en pocas palabras: humana y social. En tanto memoria pública, está sometida al cambio: político, generacional, individual. No puede ser almacenada para siempre, ni puede ser asegurada a través de monumentos; en ese aspecto, tampoco podemos confiar en los sistemas digitales de recuperación de datos para garantizar la coherencia y la continuidad. Si el sentido del tiempo vivido está siendo renegociado en nuestras culturas contemporáneas de la memoria, no deberíamos olvidar que el tiempo no es únicamente el pasado, su preservación y transmisión. ",43

\footnotetext{
${ }^{42}$ Viaje del papa Francisco http://www.diarioarmenia.org.ar/la-visita-del-papa-francisco-a-armenia-seramuy-intensa/

43 Huyssen, Andreas. "En busca del futuro perdido" Cultura y memoria en tiempos de globalización, México, Fondo de Cultura Económica, 2002.
} 
Sentí que había silencios, otra vez, una inmensidad de silencios como el paisaje que lo rodeaba. El Memorial está lejos de todo y cerca de nada. Nada a su alrededor o más concretamente; ninguna construcción, ni siquiera el Museo del Genocidio Armenio se interpone, el museo ${ }^{44}$ se encuentra construido subterráneamente, esto me impactó mucho, está debajo de la tierra y se recorre con una larga caminata...muy larga, bajando; paralelamente a las imágenes de las deportaciones y otros crímenes.

"Las politicas de la memoria, cada vez más fragmentadas de los específicos grupos sociales y étnicos en conflicto, dan lugar a preguntarse si acaso todavía son posibles las formas consensuadas de la memoria colectiva; de no ser así, de qué manera se puede garantizar la cohesión social y cultural sin esas formas. (...). En tanto memoria pública, está sometida al cambio: político, generacional, individual. No puede ser almacenada para siempre, ni puede ser asegurada a través de monumentos; en ese aspecto, tampoco podemos confiar en los sistemas digitales de recuperación de datos para garantizar la coherencia y la continuidad." 45

El bloqueo entre Armenia y Turquía, el cierre de la frontera que se ve allí mismo, afecta directamente la estrategia de una "memorialización" del pasado. La frontera cerrada es ahora parte del Memorial, como también lo es el Ararat "del otro lado", en Turquía. El duelo en ambos lados de la Armenia histórica.

\footnotetext{
${ }^{44}$ Museo del Genocidio Armenio http://www.genocide-museum.am/eng/index.php

45 Huyssen, A. Op. cit.
} 


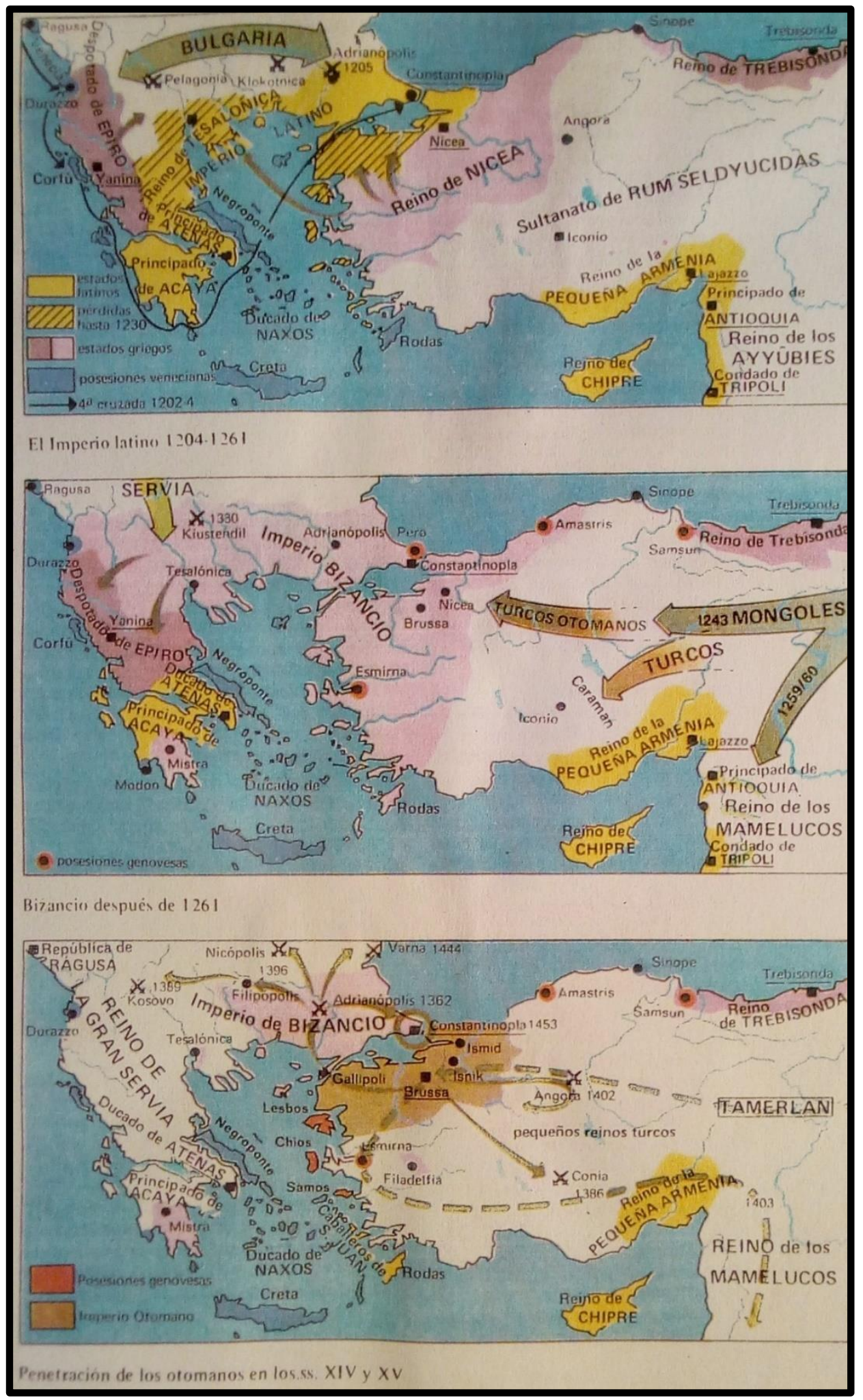

Edad Media / Últimas Cruzadas. Fin de Bizancio (1204-1456) Kinder, H. Hilgelmann, W. Atlas histórico mundial. Tomo I. De los orígenes a la Revolución Francesa. Madrid, Istmo, XVIII edición 1996. 


\section{TERCER MOMENTO}

\section{La búsqueda de testimonios por el Derecho a la Verdad. Buenos Aires 2001-2011}

En Buenos Aires, finalizando el año 2000, el Escribano Gregorio Hairabedian, con el patrocinio letrado de su hija Dra. Luisa S. Hairabedian, inició un juicio por el reconocimiento jurídico del Genocidio Armenio relativo a la búsqueda de la verdad y la lucha contra la impunidad del genocidio de armenios por parte del Estado de Turquía durante los años 1915 - 1923, del cual específicamente fueron víctimas integrantes de su familia paterna y materna radicada en dicha época en los vilayetos de Palú y Zeitún, respectivamente. Se sumarían también, como querellantes, otras instituciones armenias conformando una demanda colectiva ante la justicia argentina. ${ }^{46}$

El veredicto con la presentación de pruebas y el escrito judicial que analiza las mismas le solicita al juez que dicte sentencia; el Dr. Oyarbide resolvió que Turquía cometió GENOCIDIO contra el pueblo armenio y puntualmente contra la familia de Gregorio Hairabedian. ${ }^{47}$

Se abre aquí la posibilidad de un tercer momento paradigmático, escuchar a los sobrevivientes en Buenos Aires.

\footnotetext{
${ }^{46}$ La Institución Administrativa de la Iglesia Armenia, Asociación Cultural Armenia, La Cámara Argentino Armenia de Industria y Comercio, Unión Cultural Armenia, Unión Compatriótica Armenia de Marash, Asociación Tekeyan, Unión de Residentes Armenios de Hadjin.

47 La Fundación Luisa Hairabedian puso a disposición pública los documentos del proceso http://www.verdadyjusticia.org.ar/www/areas/catcms/9/pub/185/Juicio-por-la-VerdadelGenocidioArmenio-20012011
} 
En el año 2009 con motivo de las Jornadas Buenos Aires Armenia realizada en La Manzana de Las Luces, ${ }^{48}$ produje la muestra "Los armenios en Valentin Alsina" con un acervo que sumé al de mis abuelos con la ayuda de distintos referentes de la comunidad armenia del barrio. Además, coordiné la programación de los paneles temáticos. Uno de ellos fue "Genocidio y negacionismo". En ese marco se expuso sobre el "Aporte de la Argentina al reconocimiento del genocidio Armenio" con Leandro Despouy y Sergio Nahabetian, Rita Kuyumciyan habló acerca de la "Negación del genocidio armenio. Un duelo perturbado" y finalmente "Los efectos del negacionismo en la construcción de la identidad armenia a través del relato de sus sobrevivientes”. Fueron Lucila Tossounian y Alexis Papazian - presentados allí como miembros del equipo Exilio político armenio en la Argentina, FFYL-UBA-, quienes compartieron el trabajo de conformación de este archivo oral. ${ }^{49}$

Hasta ese momento no estaba interiorizada acerca de la existencia de un trabajo de registro de testimonios de los pocos sobrevivientes que vivían en Buenos Aires, ni del Juicio por la Verdad que llevaba adelante la familia Hairabedian contra el estado turco y más aún, de cómo podría el negacionismo ser parte de la dinámica de la identidad armenia.

\footnotetext{
48 Jornadas realizadas en agosto de 2009 en la Manzana de las Luces de la CABA organizadas desde la Dirección de Patrimonio e Instituto Histórico y la Comisión para la preservación del patrimonio histórico cultural del Ministerio de Cultura de la Ciudad de Buenos Aires. Ver programa en http://guiamenc.blogspot.com/2009/08/lunes-10-y-martes-11-de-agostojornadas.html

49 Luisa Hairabedian en vida se había contactado con el Profesor de Historia Alejandro Schneider, integrante del Programa de Historia Oral de la Universidad de Buenos Aires, UBA para recopilar con la metodología académica de "Historia Oral" testimonios orales de sobrevivientes del genocidio armenio, residentes en Argentina. Asi, se formó un equipo interdisciplinario de jóvenes académicos que recopiló testimonios de sobrevivientes del genocidio y fueron, junto a la prueba internacional recopilada, incorporados como prueba al Juicio por la Verdad. Por su parte el Tribunal citó a prestar declaración testimonial a diversos integrantes de la comunidad Armenia, en su mayoría, sobrevivientes e hijos de sobrevivientes para que declararan en el Juicio por la Verdad
} 
A pesar de los años que transcurrieron, cuando volví de Armenia visité el Archivo de la Fundación para indagar sobre ese tema en particular. De hecho, pensé y ordené algunas preguntas antes de tener los audios de las entrevistas que produjo la Fundación Luisa Hairabedian. ${ }^{50}$

En mi relevamiento me mantuve muy esquemática; así era mi guía de investigación:

a. ¿Cómo se denominaba - antes de la aparición del término genocidio (1948) - a lo ocurrido entre 1915 y 1923 con el pueblo armenio EN EL IMPERIO OTOMANO?

b. ¿Cómo y cuándo se incorporó el concepto de genocidio en la diáspora armenia en la Argentina?

c. ¿Cómo se desarrolló el concepto de negacionismo en la diáspora armenia en la Argentina?

d. ¿Cuáles fueron los modos de producción de estrategias comunicacionales en la diáspora armenia en la Argentina, sobre el genocidio negado?

e. ¿Cuáles son las prácticas de construcción de la memoria sobre el genocidio armenio en la diáspora armenia?

Las reescribo aquí con cierta dificultad...pienso cómo fue posible redactar este tipo de preguntas: ¿qué "resultados” imaginé? ¿qué podría encontrar ante tanta complejidad?

Necesité sumar un trabajo de Claudia Oxman ${ }^{51}$ acerca de los contextos en el marco de una investigación basada en entrevistas realizadas por otros.

\footnotetext{
50 http://verdadyjusticia.org.ar/fundacion/

51 Oxman, Claudia. "La entrevista de investigación en Ciencias Sociales” Eudeba, Buenos Aires, 1998.

Claudia Oxman en la primera parte de su tesis, me enfrenta con esta problemática, ya que no soy yo quien definirá el tipo de entrevistas, sino que deberé obtener información acerca del planteo de las mismas y el marco del Proyecto de investigación por el cual fueron realizadas. Tratándose del único archivo conformado por entrevistas realizadas a sobrevivientes del genocidio armenio que vivieron en Buenos Aires., se le agregan ciertas especificidades que por el texto de Oxman podría precisar a través de lo siguiente: “(...) el contexto suele desagregarse según la esfera que se considere más pertinente para el análisis. A partir de
} 
Los diferentes contextos que comencé a identificar gracias a este estudio, determinaron roles y me alejaron de esta primera guía de preguntas con las cuales intentaba abordar los testimonios.

Para ello necesité "crear" un contexto más no para desagregar sino para involucrarme. Oxman señala que: “(...) en la entrevista de investigación el proceso de producción consiste en un hacer persuasivo o hacer creer y el proceso de interpretación, en un hacer interpretativo o creer. A través de ambos procesos tiene lugar la construcción semántica de la verdad, que aquí tampoco se entiende como representación de un estado de las cosas sino como efecto de sentido."

Por lo tanto, tendré especial consideración acerca del distanciamiento entre la lectura de la transcripción de cada entrevista, la escucha y la selección que realizaré, como un momento que da origen a un objeto cultural; construido con momentos entre los entrevistados y entrevistadores, con quienes preguntan y quienes responden, pero también con quien las escucha.

Me incliné por un método de recreación cuyo principal objetivo es narrar de un modo coherente y verosímil cada testimonio escuchado con el fin de no me alejarme o distanciarme tanto de la producción de las mismas.

Los contextos se fueron configurando: el contexto inicial fue el acceso a ese archivo oral y la frustrada búsqueda de las respuestas a mis preguntas "guía". El segundo contexto que comencé a identificar es el de la significación. Como dije, esas entrevistas no fueron pensadas, diseñadas ni producidas por mí y eso condicionó el hecho de no haber tomado decisiones en torno al tipo, estructura, los objetivos, la duración, las repreguntas, o la posibilidad de volver a realizarlas.

esto, Bauman (...) enumera seis contextos diferentes: contexto de significación, contexto institucional, contexto del sistema comunicativo, base social, contexto individual y contexto de situación.” 
"Un texto es discurso vuelto descontextualizable. La entextualización bien puede incorporar aspectos del contexto, de tal manera que el texto lleva consigo elementos de la historia de su uso." $\mathbf{5 2}$

El archivo está determinado por el contexto institucional: quienes diseñaron el plan de trabajo y el proyecto además de ser descendientes de armenios, estaban llevando adelante un proceso judicial. Un contexto de situación, que es casi un punto de inflexión: en aquel momento, año 2006 - 2008, la edad de las personas entrevistadas estaba entre los 85 y 90 años. ${ }^{53}$ Es por ello que mientras escucho y leo las transcripciones, habilitada en mi contexto de recreación, completo las entrevistas para darle un uso poético-político.

52 Para no cosificar el texto como la mera transcripción de los mismos, trabajaré en la entextualizaciòn y contextualización, paso que le siguen a consignar los contextos. Dice Oxman: “(...) un texo es discurso vuelto descontextualizable. La entextualizaciòn bien puede incorporar aspectos del contexto, de tal manera que el texto lleva consigo elementos de la historia de su uso." Tener especial atención en cómo seleccionar los temas y presentar el producto como un objeto cultural; producto a su vez de otro momento en el cual fue incorporado a la cultura con distintos marcos, y que no sólo son lingüísticos. Cuando Oxman habla del desborde del marco lingüístico me acerca a la idea de recontextualizar sobre lo contextualizado por quienes imprimieron las líneas de las entrevistas. Trabajar con el concepto de entrevistas originales y producto de las entrevistas. Poder diferenciar los dos (o más) modelos culturales. La contextualización (como decía, para no limitarme a cosificar el texto), me llevará a insistir en los marcos y modelos culturales tanto del momento de producción de las mismas y sus protagonistas como este momento de escucha y transcripción. Una vez que comienzo con el trabajo de convertir las entrevistas en testimonios, considerar: "Para las investigaciones etnometodològicas como también para las provenientes de la corriente interaccionista (Goffman 1964), son dos ejes claves la filosofía del lenguaje y la acción de Wittgenstien y la fenomenología de Husserl. Ellas ponen en primer plano el lenguaje natural como locus de la pertenencia a una comunidad: ser miembro de una comunidad será ante todo compartir un lenguaje." Aquí hay un dato a tener en cuenta acerca no sólo de los entrevistados sino también de quiénes han realizado las entrevistas ya que como señalé se trata de una Fundación que se inscribe en la comunidad armenia.

${ }^{53}$ Las entrevistas que escuché y revisité fueron realizadas a Dikranui Dokmetzian de Khasserdjian en noviembre 2006, a Guiragoz, (Martín) Mersifonian un hombre de 90 años en agosto de 2008, a Guiragoz Deirmendjian en septiembre de 2008 y a Armen Keoroglian de Ainadzian el 26 de noviembre de 2008.

Entrevistadores Alexis Papazian, Melina, Alaghiozian, Daniel Cholakian, Miguel Tchilinguirian, Ana Gabriela Ohanecian y Greta Kalaidjian. 
Construyo escenas para la escucha pensando, tal vez, en aquello que consta en las actas que firmaron las personas entrevistadas, ${ }^{54}$ autorizan su uso "como potencial para una revisita en caso de que lo consideremos y de que el entrevistado tenga voluntad para autorizar el uso de su testimonio como prueba legal”. Mi objetivo es habilitar esas revisitas a partir del Cuarto Momento que propongo.

\footnotetext{
${ }^{54}$ En el Archivo están las actas de autorización de uso de las entrevistas que firmaron cada uno de ellos, se autoriza el uso de su testimonio para ser parte de otros juicios por la verdad, y (en aquel momento) en la causa judicial de La Fundación Hairabedian.
} 


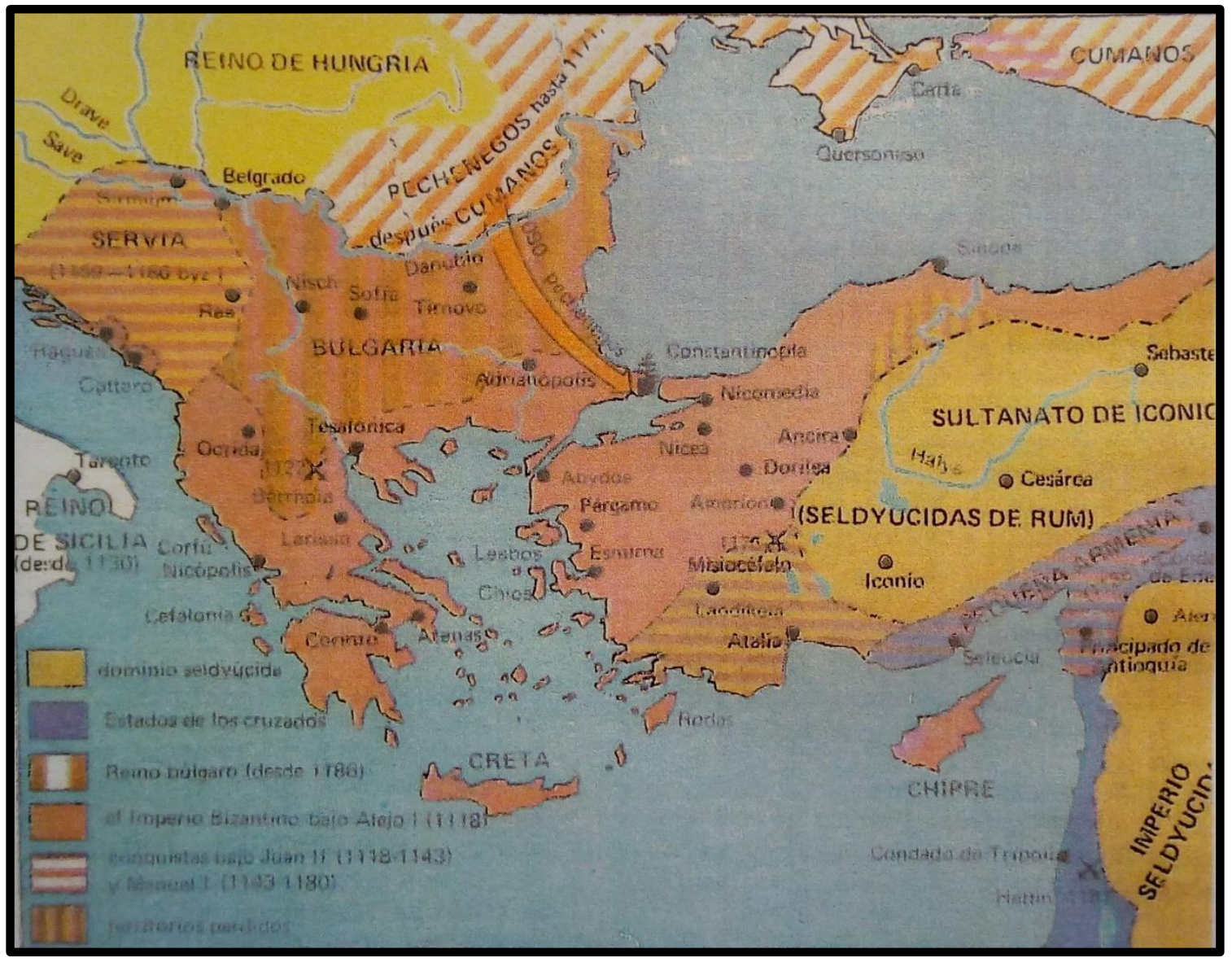

Edad Media / Bizancio en el s. XII Kinder, H. Hilgelmann, W. Atlas histórico mundial. Tomo I. De los orígenes a la Revolución Francesa. Madrid, Istmo, XVIII edición 1996. 


\title{
CUARTO MOMENTO
}

\section{Escuchar a los sobrevivientes en Buenos Aires.}

\section{Lo que dice Dikrauni.}

\section{Recreación basada en la entrevista realizada por la FLH ${ }^{55}$ a Dikranui Dokmetzian de Khasserdjian en noviembre 2006}

\begin{abstract}
Alexis, Melina y Daniel son descendientes de armenios y están trabajando en la recuperación de los testimonios de los sobrevivientes del genocidio armenio. De algún modo están investigando sobre el pasado de sus familias. Apenas escucho el primero de los audios siento ese pasaje abrupto. Las fichas de referencia funcionan de auxiliares, me indican quién es quién según el diálogo. Hago una primera escucha para identificar las voces de cada uno. Me interesa especialmente transmitir la sensación de no conocerlos con anterioridad y de saber que mi única posibilidad es escucharlos para conocerlos.
\end{abstract}

Alexis conversa con Dikrauni, pregunta sutilmente, es muy dulce con ella. Pienso que no tiene ganas de que este encuentro se transforme en un interrogatorio.

La voz de Dikrauni es agridulce. Escucho su risa y canta por momentos, en otros se escucha su tristeza y enojo.

Y dice:

- Hacerse turco, algunos salvaron sus vidas así, podías hacerte turco.

Cuenta cómo aprendió con su madre el arte del tejido durante los años que vivieron en Grecia. Es espontánea. Por un instante se siente incómoda... tiene miedo de caerse del sillón donde está sentada.

\footnotetext{
${ }^{55}$ Fundación Luisa Hairabedian
} 
Alexis le dice:

\section{- Nos está contando una historia muy linda.}

"Linda", entiendo, no en el sentido de belleza sino que destaca la claridad que tiene al contar y lograr el acompañamiento atento de todos los que la escuchan - donde yo también estoy incluida -. Las intervenciones de los entrevistadores son mínimas. Esto denota un microclima casi familiar y hace posible hablar de algo tan doloroso.

Le proponen a Dikrauni retomar el relato iniciado antes de grabar. Ella, mientras tanto, les muestra fotos de su juventud.

\section{- Está igual de linda...}

Y en este caso el "linda" si es por su belleza que se siente, aunque hayan pasado muchos años desde los momentos de aquellas fotos. Después del horror puede sobrevivir también la belleza...

Dikrauni habla de Drama, un pueblo griego donde se refugiaron antes de llegar a la Argentina. Su pueblo natal era Kutajia, un pueblo habitado por armenios dentro del Imperio Otomano. Nació en 1922 y desde allí, siendo una bebé, se la llevaron a vivir a Drama. Como si el nombre de ese pueblo fuese la gran paradoja de su vida. Pienso ahora que tenía 84 años aquel noviembre de $2006 \ldots$

\section{- Y, ¿por qué se fueron de Kutajia?}

- Nos fuimos porque eran turcos. Vos te quedabas, te quedabas turco, o si no eras matado, muerto. Mataban. 
"En un telegrama enviado al inspector financiero en Kutahya el 26 de septiembre de 1915, Talaat consulta “la razón por la que se deportó a los griegos (de la zona), la persona que haya emitido la orden y el lugar donde se los envió." Estambul sólo se enteró de ello en primer lugar por la queja presentada por el Patriarcado griego en la ciudad."

“A su vez, el gobierno otomano puso a disposición barcos de vapor y cubrió los gastos de los pasajes a Grecia de cristianos griegos exiliados. En un cable al distrito provincial de Tekirdag el 20 de abril de 1914, la IAMM solicita lo siguiente, "el barco de vapor con bandera griega Karmala, contratado para traer a los emigrantes griegos desde aquí a Salónica, partirá mañana temprano. Por favor, los pasajeros deben estar listos (para embarcar), ya que se deberá abonar una compensación en el caso de que permanezca (en el muelle) por más de tres días".

Traigo una de las tantas citas que tomé de los libros de Taner Akçam ya que su relato profundiza todo lo que pude haber leído hasta hoy.

- Y, a ver, ¿dónde nos quedamos? Nos quedamos en Grecia, por un lado, pero también estaba llegando a la Argentina.

Al instante interviene Daniel, cambia el ritmo de la entrevista.

- Cuando usted estaba con su familia en Grecia, ¿ustedes hablaban en armenio entre ustedes?

- Yo hablaba en armenio por el colegio, porque a mi papá a la maestra le daba un caramelo por día, (y le decía): "dale a mi hija, que lo coma, quee sepa que cuando hay armenio... en la boca para hablar, si puede hablar, entonces va a comer caramelo, sino no lo va a comer", y yo por el caramelo, me esforzaba y hablaba en armenio.

- Con mi mamá hablábamos en turco... Sí, eh, es una lucha, ¿eh? Es difícil, hablar con una persona un idioma, después hablar con el otro. Pero a mí en la escuela, los caramelos me habian hecho muy bien [risas] 
Cuenta luego lo que pasó después, escucho sobre cuando tuvieron que irse "caminando". - ¡Caminando, eh, dice "Dame la nena!”, era criatura, "dame la nena”, “No, yo no, yo, yo lo llevo, yo la llevo”, ; “dámela te dije!!”, se peleaban.

\section{- ¿Con quién?}

Melina no comprende claramente entre quiénes peleaban.

- Madre e hija, mi hermana y mi mamá. En aquel entonces mi hermana habia escuchado que la gente se cansaba de llevar las criaturas y algunos los tiraban al agua, a otros los dejaban debajo de un árbol, la criatura quedaba ahí.

“A lo largo de toda la deportación, niños y niñas fueron asesinados en el acto o abandonados para luego morir de inanición o a causa de enfermedades. En algunos lugares, junto con sus madres, morían ahogados en el Mar Negro. En la cuarta sesión del juicio de posguerra de Trebisonda, el 3 de abril de 1919, "la ratificación del testimonio de una mujer reveló que Cemal Azmi bey ordenó a los gendarmes recolectar a varones armenios y llevarlos en bote a Kumkale - En el viaje todos ellos fueron asesinados - algunos de un disparo, otros fueron lanzados al mar. Aquella misma acusación rezaba: "Cerca de Degirmendere... cargaban a las mujeres y niños en botes, los llevaban al mar y los lanzaban para que murieran ahogados. De un modo similar, la violación, el abuso sexual y la prostitución de mujeres armenias eran prácticas generalizadas en gran medida." 56

\footnotetext{
56 Una nueva cita textual de Akçam para reforzar la rigurosidad de lo que estoy escuchando.
} 
Alexis pregunta concretamente:

- Con respecto a esto, al genocidio, que ustedes lo sufrieron cuando se escaparon y, la familia de su esposo también cuando se, cuando mataron al tío, y cuando los sacaron al desierto a caminar, ¿cree que hay alguna manera de lograr justicia?, ¿o le parece que es muy dificil? O cree que, no sé, ¿qué cree que se puede hacer al respecto?

- ¿Qué se puede hacer, matarlos, todos, no dejar ninguno! ¡Matar todos los turcos, terminar! Eliminar... Ahora Dios está matando, le está dando castigo...

La justicia depositada en Dios, más allá de su primer pensamiento, aquel que se materializó en parte de la mano de Sohomon Telirian, parece ser la única forma en la cual Dikrauni entiende que se puede superar tanto dolor. Por eso el silencio entre cada fragmento de su relato.

Por eso también, interrumpí dos veces con mis notas la entrevista, sentí que debía darle a Dikrauni, a Melina, Daniel y Alexis, la intervención de Taner Ackam en esta recreación, esa certeza y ese acompañamiento de un historiador turco, para no anclarlos en ese final. 


\section{Los jóvenes turcos de Armen}

\section{Recreación basada en la entrevista realizada por la FLH a Armen Keoroglian de} Ainadzian el 26 de noviembre de 2008.

Cuentan Melina y Alexis (en la transcripción de las entrevistas), que fue el hijo de Armen quien los contactó para que se encontraran en una Casa de Descanso en Palermo donada por la Asociación Civil de Beneficencia Armenia HOM. ${ }^{57}$ Avisaron antes al personal del hogar y ese día, 26 de noviembre de 2008, llegaron alrededor de las 10 de la mañana. Armen ya los estaba esperando en la sala de estar de la planta baja, que daba a un patio. Allí se realizó la entrevista.

Más allá de lo que consignan los documentos escritos del archivo, me interesa descubrir quién es Armen a medida que avanzo en la escucha; cómo se va presentando ante mí a través de lo que escucho, tal como lo hice con Dikrauni y haré con el resto.

Armen tiene una voz pausada. Esto permite que las interrupciones/pausas por motivos externos (que son muchas) acomoden la escucha sostenida en ritmo lento. Hasta que no mencionó que quedó viuda, su voz se podía asociar a un tono masculino, un tono grave y profundo. En definitiva, escuchar tanto a un hombre como a una mujer, no es relevante para mí, pero destaco haber tenido esta sensación. Por otro lado denota mi desconocimiento sobre muchos nombres armenios.

Nació en 1918, dice “durante la guerra", en aquel momento, (el de la entrevista), tenía 90 años. Casi diez años después de grabarla la estoy escuchando, una y otra vez, como a todos. Poder escucharlos varias veces es lo más valioso de tener acceso a este archivo.

Melina y Alexis cuentan que Armen se mostró dispuesta a contestar sus preguntas, aunque reiteradas veces parecía querer dar la entrevista por terminada, dando a entender que no tenía nada más que contar. Como si creyera que sus recuerdos no tuvieran fuerza

\footnotetext{
57 https:/www.diarioarmenia.org.ar/ochenta-y-cinco-anos-de-hom-sudamerica/
} 
de testimonio, por la distancia en el tiempo y algunos desdibujamientos. Sabemos hoy que las víctimas de delitos de lesa humanidad no tienen obligación de reiterar con exactitud los hechos traumáticos por los que tuvieron que pasar, pero ese hecho no invalida el testimonio. ${ }^{58}$

Cuando habla de Gudina (Kutajia o Kutahya en Turquía actual) menciona a su mamá y a un hermano, y supone que su padre murió en la guerra. Dice "fueron" a Estambul, vivieron en /chadr/ (en turco, carpa), durante 6 meses hasta que los barcos "los trasladaron" a Salónica.

Los domingos iban a la iglesia para ver si en la pared aparecía un papel donde dieran el paradero de los familiares desaparecidos. Se informaba: "Fulano está en Norteamérica", "Mengano está acá, allá”, y cuenta que a su hermano lo encontraron en Salónica.

Habla muy pausado, en tono grave...Con insistencia señala que todo era gratis allí, en Estambul, la comida, los barcos.

Se escuchan voces de fondo, de gente que pasa por allí, pero ella no se distrae, sí los demás. Sigue con su relato.

- Mi papá no volvió, yo a mi papá no lo conocí, se murió por ahí. Mi hermano volvió.

- No eran soldados, eran rehenes. Los llevaban caminando de un pueblo a otro, de un pueblo a otro caminando así. Los turcos los llevaban así a la guerra.

- Era muy feo todo eso, de los turcos... Nos odiaban, /iavur/ decían a nosotros a los armenios, /iavur/

Alexis le pregunta si sabe lo que significa "iavur" ya que no era la primera vez que escuchaba la palabra. Pero Armen no encontraba la traducción, le decía sencillamente que era una palabra fea, debería ser una palabra fea, /iavur/...

\footnotetext{
${ }^{58}$ En el caso argentino por causas vinculadas al terrorismo de estado se han establecido derechos a las víctimas - testigos en cuanto a que no están obligados a recordar con exactitud los hechos traumáticos vividos. Existen además programas de acompañamiento a las víctimas.
} 
- Significa infieles,

- Lo sé porque me lo contó una señora como usted que lo sabía.

- A las mujeres las dejaron... Y y las mujeres se arreglaron como pudieron. Me acuerdo como un sueño que vivíamos en un sótano en la casa de unos turcos que hasta que termine el batifondo, qué sé yo qué clase de batifondo era... Y (después) salimos de ahi ya, fuimos a Estambul. Alli ayudaron los dinamarqueses...

Interrumpen para pedir permiso de pasar la enceradora en el lugar donde se hacía la entrevista.

- Habia /dest'/ (en turco, vasija), habia /dest'/ en las calles, agua, /chesmé/ (en turco, canilla), /bard'/, habia de /chesmél en las calles ibas con /dest'/ y llenabas.

Por varios minutos, nuevamente, se empiezan a escuchar voces, vienen a atender a un señor que estaba cerca. Le proponen a Armen cambiar de lugar, y pienso que sería una gran idea ya que también sentía las distracciones. Armen se ríe, Melina y Alexis señalan en la transcripción que es muy pícara, evidentemente ella era la que menos perturbada estaba.

- Alfombra tejía. Trabajó de eso, de soltera, de casada también porque eran pobres, y tuvo seis hijos, el primero vivió. En el interin murieron..., cuatro... Varón, mujer, de tres años, de cinco (años), de seis (años). No acostumbraban llevar al médico, hacían remedios caseros, entonces se murieron, entonces se quedaron con uno, dijeron “(bueno), (vamos) a comprar otro”, y /sa/ me encontraron a mi!

Las risas que contagió Armen contando con alegría su llegada después de tanta muerte hicieron que Alexis se relajara y confesara: 
- Yo le pregunto a veces porque en realidad en mi familia, por ejemplo, se contaba muy poquito, porque a mis abuelos no, no, no (se corta)

Ella sigue con su relato anterior...

- Me acuerdo que mi mamá cerró la puerta con llave y agarró la llave pensando que va a volver a su pueblo (con una media risa), cuando vinimos a Estambul. Y nunca volvió.

No distingo si es incredulidad o ironía. Interrumpe otro señor del hogar que se involucra en la conversación por unos minutos, comienzan a hablar de un postre y participa también de la charla.

- Yo vine de Antep

- Vos viniste de Antep, sí

- Aintepsí

- Aintepsí?

Armen dice

- ¡Hay de todo acá!

El señor se retira de la conversación.

- Pero ahora están cambiado las cosas, tal es así que dos veces recibimos gente turca a cenar.

- ¿Acá?

Preguntan y yo también, ¿a qué se refiere con que hay de todo acá?

- Acá. Tengo nieto que viaja. El hijo mayor de mi hija, tiene veintinueve años ahora. Conjunto tiene, tango está muy de moda, lo llaman, pago, hotel pago, comida pago, todo pago, encima pagan a ellos también. Y se va. Conoció todo Europa y a unas personas turcas. 
- Recibimos acá, porque él conoció turcos y cuando les dio la dirección y vinieron acá, invitamos a cenar. Y /olma mal' eld' amma old'/ (en turco: no tendría que haber pasado, pero pasó), dijeron, por la guerra.

Armen habla de los jóvenes turcos amigos de su nieto y del cambio con respecto a haber dejado de lado un "fanatismo". En esas cenas y conversaciones coincidían en eso de /olma mal' eld' amma old'/, no tenía que pasar. Armen en este momento aclara que hablaba en turco porque así se comunicó toda la vida con su madre. Ella aprendió el idioma armenio en Argentina, además del castellano.

- Por la raza, querían que seamos turcos, y los cristianos no aceptaban ahí empezó la guerra... Por la raza...

[cambio de lado del casette]

- Usted diga cuando se cansa y nosotros cortamos un poquito.

- Es que no tengo nada más para contar yo.

Se produce una pausa.

- ¿Usted qué opina de la relación entre Armenia y Turquía hoy, que recién nos contaba...? ¿Qué, cómo tiene que ser?

- Hay que aceptar.

- ¿Qué cosa?

- Que la juventud tiene otra mentalidad ahora en la Turquía, no es como antes.

Armen transmite desdicha y lamento. Aclara que hasta que esos encuentros no se hicieron, ella guardaba recuerdos y sensaciones de rechazo.

La conversación previa con su nieto había sido dura: 
- ¿Cómo invitaste?, eh, dije, todos, los turcos encima, dije, ¿vamos a dar comida? Le reté y todo a mi nieto. Pero cuando vinieron, dos muchachos, de buenos, ide buenos! Dije, “cómo se cambió los turcos, no, no, Turquía no es asi ahora, lo lamentamos mucho, dijeron.

- ¿Y antes cómo era?

- Los turcos odiaban a nosotros, nosotros odiábamos a los turcos. Ellos querían que nosotros seamos turcos, y no aceptaron, no

La entrevista duró alrededor de una hora; Armen les mostró, antes de terminar, unos diarios que había mencionado durante su relato. Recorriendo la casa de descanso, les presentaba a otras personas que ella consideraba que también podrían ser entrevistadas, ya que "conocían la historia de la armeniada". Ahora sí, la despedida en la puerta.

- Hoy tocó, hoy tocó un día libre. Todos tenemos actividad.

\section{- ¿Qué actividades hacen acá?}

- Los, hacemos gimnasia, masajes nos hacen, y (después) traen números, cantantes, (bailantes)... Bueno, hacen. Una vez por mes hacen todos los cumpleaños. 


\section{El cumpleaños 92 de Guiragoz}

\section{Recreación basada en la entrevista realizada por la FLH a Guiragoz Deirmendjian en septiembre de 2008}

El audio comienza con la conversación iniciada, reconozco a Guiragoz y voy leyendo los datos de referencia del archivo. Habla rápido. Pregunta, responde, genera la repregunta, se percibe mucha fluidez y energía, entusiasmo, ganas de contar muchas cosas.

Habla de genocidio, repite varias veces: genocidio. En turco, en armenio, en castellano, mezcla así su relato con voz fuerte y clara. No se distrae con los sonidos del ambiente. Música, voces, risas, sonido de vajillas, de vehículos, están en un bar.

Golpea la mesa cuando enfatiza. Se escucha de fondo Billy Jean de Michael Jackson. Cuando la música de fondo se hace notar él levanta el tono, enfatiza, golpea la mesa.

Los entrevistadores preguntan una vez cada uno. Cuenta que sus abuelos y sus padres participaron de la construcción del puente sobre el río de Marash, otro de los pueblos del imperio otomano con habitantes armenios, y además cargaban las piedras para la construcción. Eso les había otorgado por parte de los turcos cierto respeto, pero no puede evitar relacionar esto con la demora en hacerlos "caminar", irse de allí.

Primero, dice, confiscaban las armas de los armenios y después, el genocidio.

- Esto me lo contaron. Mis abuelos contaban esto, claro. /Sirvn/, /sirvn/ significa, /sirvn/, vía, caminar, venía la caballería, con todo su instrumento, machete, no sé qué, atropellaba a todos. Miles y miles, no quedaba uno vivo.

- Entonces después de esa matanza, esa gente, papi..., la gente armenia que se salvó por la política de los turcos que lo perdonó la vida. Varios porque éramos casi conocimiento de ellos, muy conocimiento. Papá ingeniero, al abuelo, el otro, fulano, mengano, este, ahí empezamos, la lucha.

- Había un colegio ahí, ¿no?, /colés/decían. Ahí se internaron como trescientos cuatrocientos, quinientos armenios se escondieron. ¿Qué pasaba? Los turcos 
lo esperaban, no podían entrar, entonces de allá ellos de /colés/ les tiraban algunos para afuera. Y de allá los turcos, ¿qué hicieron? Hicieron todo incendiaron, con molotov, al quedar adentro murieron todos. jNo quedó, ni uno quedó, papito! Después entonces de Marash, empezamos a escapar. Porque nos mataban igual, por más que habia amistad, escapamos.

- El odio era porque éramos "ian". Hay muchos que se sacan apellido, cuántos vienen de Estambul últimamente, que se cortaban apellido, con todo eso (...)

- Escapamos a la casa de una tía, por la montaña, /hachds/ era pobrecita, nos sobrevivimos mamá, papá, familia, todo ahí. A la noche, sentíamos los tiros biiiiiiiiiim [imita el sonido], yo era chico, zumbaba, tiros, tiros, nos van a matar decían, nos van a matar a todos.

Se emociona. Recién ahora hace un descanso.

Pide que le pregunten, que le hagan una pregunta ahora para cortar por la angustia que le da recordar a sus padres. Guiragoz tiene un ritmo acelerado, pero cuando menciona a sus padres se detiene. Greta, Miguel y Melina se dan cuenta de su angustia. Comienzan a hablarle del lugar porque de fondo la música seguía, las voces, las risas... estaban en un restaurante de medio oriente de Buenos Aires.

- iEl veinte de agosto cumplí noventa y dos años! Y acá me hicieron una fiesta en Garbis, acá en Garbis ¿ves? Mi hija, mi hija Analía, trabaja acá. Lee la borra del café y tira las cartas.

Por unos instantes en los cuales la tristeza se sentía en la voz de Guiragoz pensé que ya no iba a poder hablar más. 
Sin embargo, comenzó con un relato sin interrupciones nuevamente.

- La matanza fue porque era inteligente el armenio. El armenio era inteligente, iba arriba siempre. Trabajador, triunfaba. Los turcos no. Te saqueaban, odiaban. Odiaban el apellido.

De repente se corta la música, pero sigue el ruido de la vajilla y de los autos, como si estuvieran solos en el restaurant.

Guiragoz está por nombrar al responsable del genocidio, y se genera una ansiedad por saber a quién va a señalar. No tienen a mano la cronología, pero se sugieren nombres, ¿Enver? ¿Talaat? ¿Quién gobernaba Marash en ese momento? Queda pendiente por un instante la respuesta, prefiere contar otra cosa...

- Recuerdo, me voy a Recoleta, hay un lugar donde vino tres músicos turcos. Me dijo un sobrino que había ido, jandá a ver lo que son esos tres músicos! Voy ahí, Centro Recoleta, un rincón al lado de la Iglesia. Uno que tocaba el /dumbek/, otro tocaba la caña, y otro (golpea la mesa) la cítara. El que tocaba, eh, el /dumbek/, ¡ay qué voz que tenía, lamán, amán, amán/! Habrán invitados turcos ahí. mí me salía de adentro, /iashál! decía yo, de adentro. Una vez que terminan esto, le voy a dar un beso a cada músico, entonces, no volvían los músicos, y veo que sale un señor alto dice es el embajador turco, alto, embajador. Me mira. Yo soy Guiragoz Dermendjian, le digo yo. Nací en Marash, ah”, Amán,

Dice algunas palabras en turco

- “qué bien hablás en turco”, me dice el embajador. Me felicitó, dice qué bien que hablas el turco, ¿no fuiste a Marash?, le digo yo. No, él me dice a mí, jsi yo fui a Marash!! (dice algo en turco y ríe).

- ¿Y cuál es el sentimiento que usted tiene hoy para con los turcos?

- Naada, mirá, ya está, ya, ya pasó.

\section{- ¿Cree que vale la pena buscar alguna forma de que se reconozca?}

- Mirá, te digo esto: pará, ahora. Mirá, mirá lo grande. Turquía fue a jugar a Ereván, el presidente Sarkissian con el turco, tomaron un café (golpea suavemente la mesa), dos veces salió en Clarín, Crónica. Turquía fue a Ereván, 
digo se van a matar estos, ¿¿te imaginás turco allá jugar al fútbol?! Ganó Turquía dos a cero, y después el presidente Sarkissian se juntó con el turco. Acordate que esto, va a haber una paz ahi ahora. Seguro.

\section{- ¿Y usted qué opina?}

- Va. Yo, yo opino bien, que van a reconocer genocidio, porque imaginate.

- ¿Pero usted cree que puede haber paz si no reconocen el genocidio?

- Tiene que reconocer. El turco con Sarkissian que se juntaron, van, van a reconocer. Porque Monte Ararat que está pegado a nosotros que nos dé de vuelta...

- ¿Y por qué piensa que no lo reconocen?

- De perro que son, de malo que son, mami. Si saben que un millón seiscientos mataron, ¿cómo no van a reconocer? ¿No quieren?, bueno, no quieren, ahora con la política de Sarkissian y el turco que se juntaron, yo creo que va.

Todas las entrevistas que aquí se recrean ocurrieron entre los años 2006 y 2008. En el 2009 la Diáspora armenia se opuso a la firma de los Protocolos. Por eso Guiragoz habla de la cuestión política. ${ }^{59}$

\footnotetext{
59 Tema desarrollado en el capítulo La diáspora armenia entre la negación y el negacionismo.
} 


\section{El orfanato, la historia y las canciones}

\section{Recreación basada en la entrevista realizada por la FLH a Martín Mersifonian un hombre de 90 años en agosto de 2008.}

Guiragoz (también llamado Martín) volvió a Armenia, es lo primero que cuenta, lo primero que escucho. No fue planeado, fue un viaje definido casi de un día para otro. La entrevista "formal" no empezó, Alexis y Ana Gabriela le proponen iniciar de una manera más "ordenada" el relato y en todo caso retomar. Guiragoz sigue hablando de su viaje un buen rato. Viajó a Armenia cuando tenía 76 años. Hace cálculos de años, de sus años. Hace comparaciones entre distancias de ciudades acá y allá. Habla en armenio por momentos y repite para comprobar si lo entienden. Mezcla la historia turco griega y turco armenia. Cada tanto pregunta por algunas palabras en castellano, para poder explicar mejor, tiene una voz grave y áspera.

Cuando finalmente retoman las preguntas, Guiragoz cuenta que nació en 1910 en Cesárea. Fue "adoptado" por otra familia armenia. El apellido Mersifonian lo tiene desde los 5 años.

Fue a un orfanato a los 11 años. Allí le enseñaron la historia armenia. Las canciones patrióticas. Las leyendas heroicas.

Se me hace muy difícil entender lo que dice. Copio un fragmento, es parte de la transcripción, acudí directamente a ella para leer los sonidos. Alexis y Ana intentan traducir varios vocablos, pero eso lo hace más confuso para mí. Ya no distinguen si la palabra es en armenio o en turco, en uno y no en otro. Para mí son sonidos, pero también son las voces del territorio, me acerco a él. 


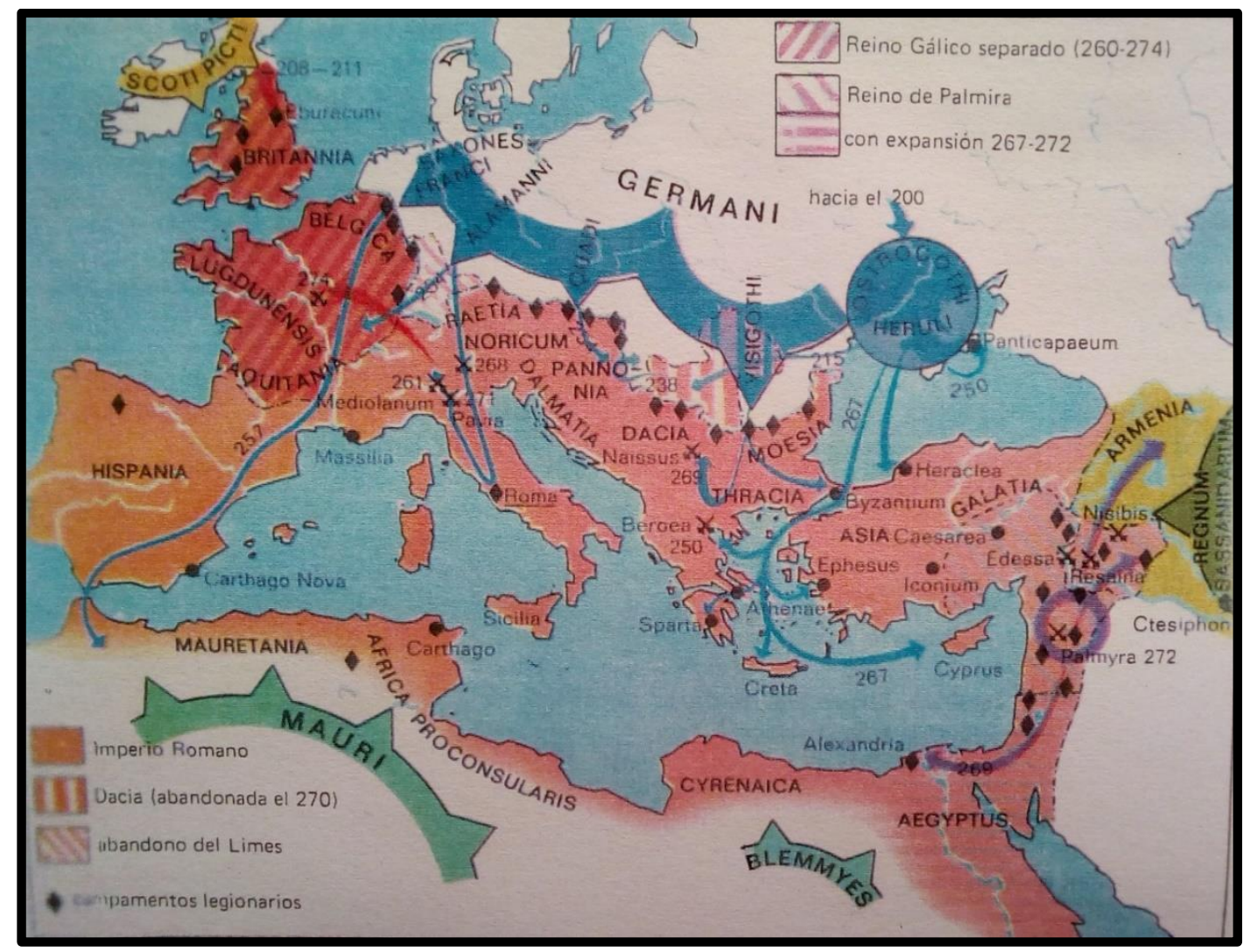

Antigüedad - Roma / El Imperio romano en el s. III. ${ }^{60}$

Antranik (...) Serop gse [muchacha] oglú [hijo]... askin hamar [para la patria]/. Eh, se va a dar la vida a suu, es /Sozé/, movete, /szinvatz [derivado de szinvor, soldado] badrastatz [preparados] kesi gu' spasenk [te esperamos] gu cancgor [venimos]/, venimos, dice (Serop?), para ayudar a usted, y tan eh, los dos, se hizo militar, lugar del, marido, él hizo! Ya era general él, /Sosan/, mujer!

Pero hay otros pasajes y dice:

\footnotetext{
${ }^{60}$ Kinder, H. Hilgelmann, W. Op. Cit.
} 
- A Turquía la manejaban los armenios ijesto no es un cuento chino!! ¡Es verídico!!

Imagino que están cerca de una ventana que da a una parada de colectivos,se oyen frenadas, abrir y cerrar de puertas, los arranques, las bocinas.

Cada vez que habla en armenio, sin que le pregunten, él aclara el significado, creo que porque entiende que quienes lo entrevistan saben algunas palabras y otras no, (aunque sean nietos de armenios).

Cuando se trata de comida, hay risas y entusiasmo por mostrar que, eso sí, lo saben todos.

- ¿Y a sus padres se los habían llevado antes?

- Cuando empezó el genocidio.

En este caso también, guerra y genocidio están perfectamente diferenciados.

- ¿Apenas empezó?

- Al desierto llevaron, desierto ya era la noche oscura, la luna, solamente se veía la luz para caminar... No sabíamos dónde es ni nada, no sé cuántas horas, siete horas, diez ocho horas, acá caballo tienen hambre, las mulas, y (tenemos también nosotros hambre...)

Con un ritmo más pausado, comienza a contar un diálogo con sus abuelos en medio del desierto.

- De lejos se veía todo, la luna... Y abuela "mirá dijo: lejos lejos ahí se ve una luz como estrella, ese no es estrella, es luz natural", dice, abuela. Y yo miraba, otro miraba... Y lo vieron las tías y puede ser.

- Mirá acá vamos a morir. 
- Nadie hay, no hay casa, no hay gente. Algunos vienen algo le roban, lo matan, se terminó. Entonces abuela le dijo; yo me voy. El abuelo estaba sentado fumando cigarrillo, no lo fuma el cigarrillo porque con avión no había, pero sabíamos que había aviones de algunas cosas chiquitas, no grandes, dicen, vigilan tal vez, (entonces) apagaron cigarrillo para que no...

\section{- ¿Haya luz?}

$-S i$.

Trabajaron en la construcción de las vías del tren para Alepo, Siria. La idea era subirse a un tren de carga, esconderse ahí y llegar a Alepo.

\section{- ¿En el tren iban escondidos?}

- Escondidos, escondidos. Tapados con frazadas, y bolsas que había también allá. Taparon para que el fuego que sale, porque se quema quebracho, carbón, y viene encima.

Llegaron a vivir por un tiempo en una ciudad, alquilaron una casa. No especifica bien en dónde era, pero una noche escuchan gritos... Su voz se acelera, como si se acelerara primero la respiración y luego el sonido. Entonces aparece el recuerdo:

- iEl que guardó algunosss inmigrantes armenios que saque afuera, sino sabemos, vamos a fusilar, vamos a colgar! /gajhagán hanenk/, en armenio colgar /gajhagán/. Y los otros (se asustaron) yyy a nosotros dijo: nosotros no podemos guardar. Este /Shamal Pashá/ era gobernador de allá, ese /Shamal Pashá/ tic, lo eliminaron los armenios, en mil novecientoveintiuno.

La voz de Guiragoz está cargada de emoción, y se torna rasposa, aspirada. Habla de los héroes y de las batallas, y puedo percibir que sus entrevistadores lo escuchan con suma atención. Yo también sigo con absoluta concentración el caudal de datos que atesora. 
Le hacen saber que se entusiasman con su ritmo, pero también que necesitan un descanso por momentos. En cambio, Guiragoz no necesita descanso, recuerda que desde chico le decían que era muy charlatán. Sus recuerdos están cargados de personajes, son muchos datos, nombres, momentos, territorio y memoria.

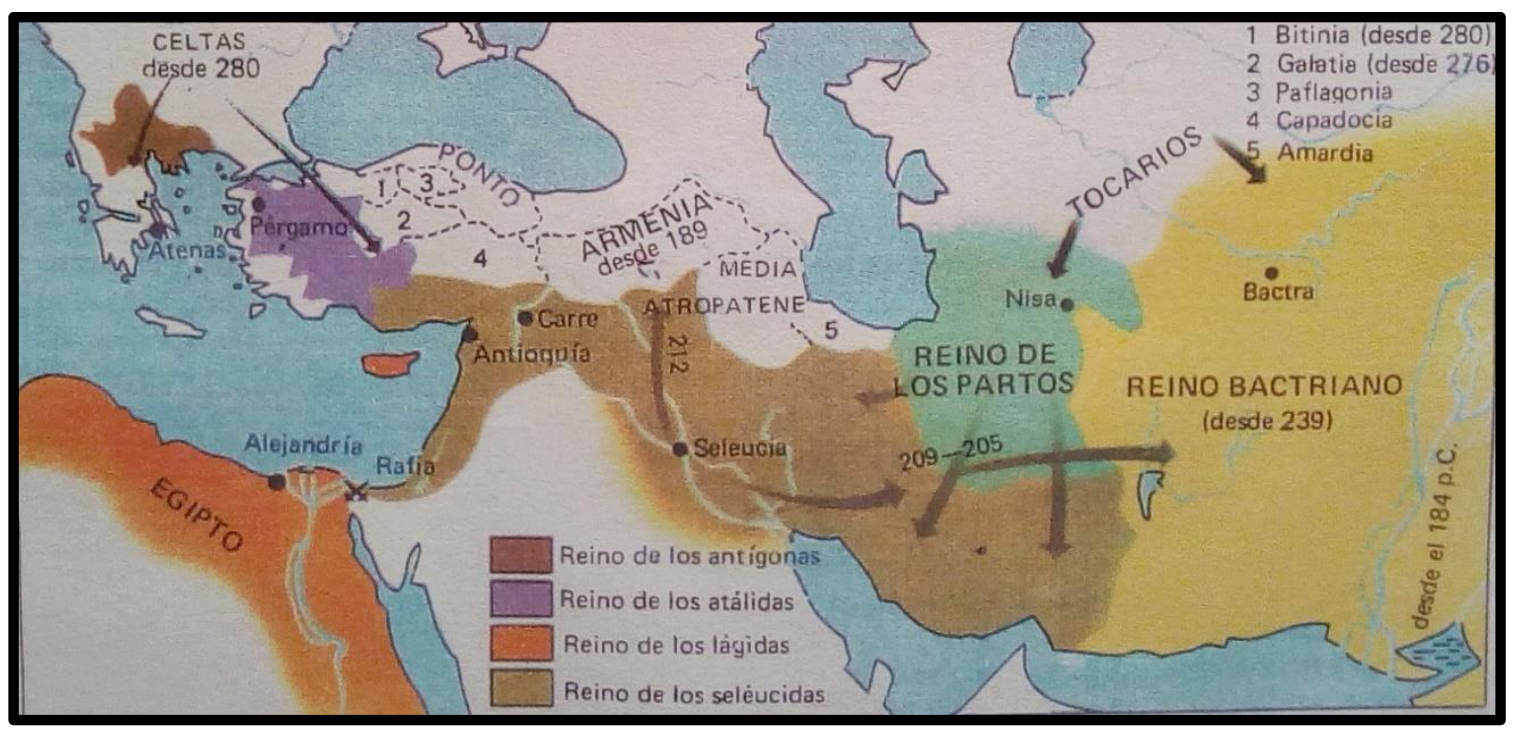

Antigüedad - Helenismo. Reino de los Diádocos en 180 a.C. ${ }^{61}$

- Antes de Cristo, que estaba Armenia, natural. Ahora, nuestro, país, Guesaria, está conquistado por los armenios, y se engrandeció Armenia

\section{- Sí}

- Y con grande [...] quiere decir mundial, como Alejandro magnate.

- Si

- Ese /Ardashés/le dieron la mano como O'Higgins con San Martín. Así, lo hemos tenido historia extraordinaria armenia, no se crea que estamos pagos, que venimos acá nosotros.

Hace silencio y recuerda. Bate las palmas como si se felicitara a sí mismo al recordar y en ese instante se manifiesta y sitúa.

\footnotetext{
${ }^{61}$ Kinder, H. Hilgelmann, W. Op. Cit.
} 


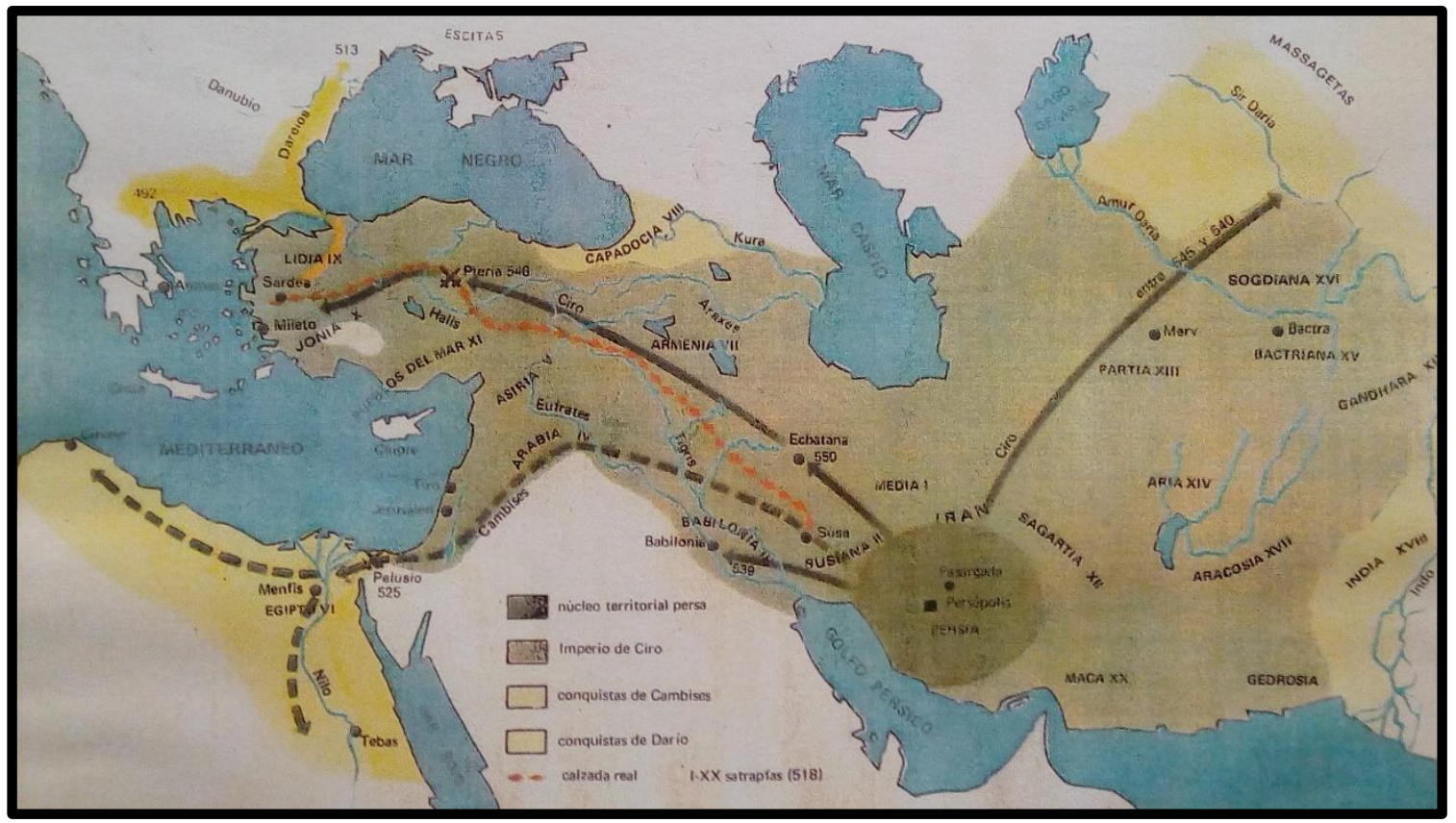

Primeras civilizaciones. El Imperio Persa. ${ }^{62}$

- Buen, el hermano se llamaba/Vaghan/. Siguió la guerra, hasta que ganamos la guerra, lo matamos todos curas de persas, se fueron, persas hicieron con nosotros amistad. Ahora único turco mahometano que hay amigo, son persas; que los persas lucharon con /Vartán Mamigonian/. Ese tiempo éramos ateos, no éramos cristiano. Y de, había (...) para luchar, pero éramos cristianos armenios, pero ellos no, ellos no eran mahometanos, eran otro, respetaban fuego, eh, oootra cosa.

Así es el ritmo de su memoria, emite sonidos que lo acercan a la melodía para llegar a la letra, los datos, la lengua. Cantar es de algún modo como llegar a su tierra, a su origen, a su ser armenio.

\footnotetext{
${ }^{62}$ Kinder, H. Hilgelmann, W. Op. Cit.
} 


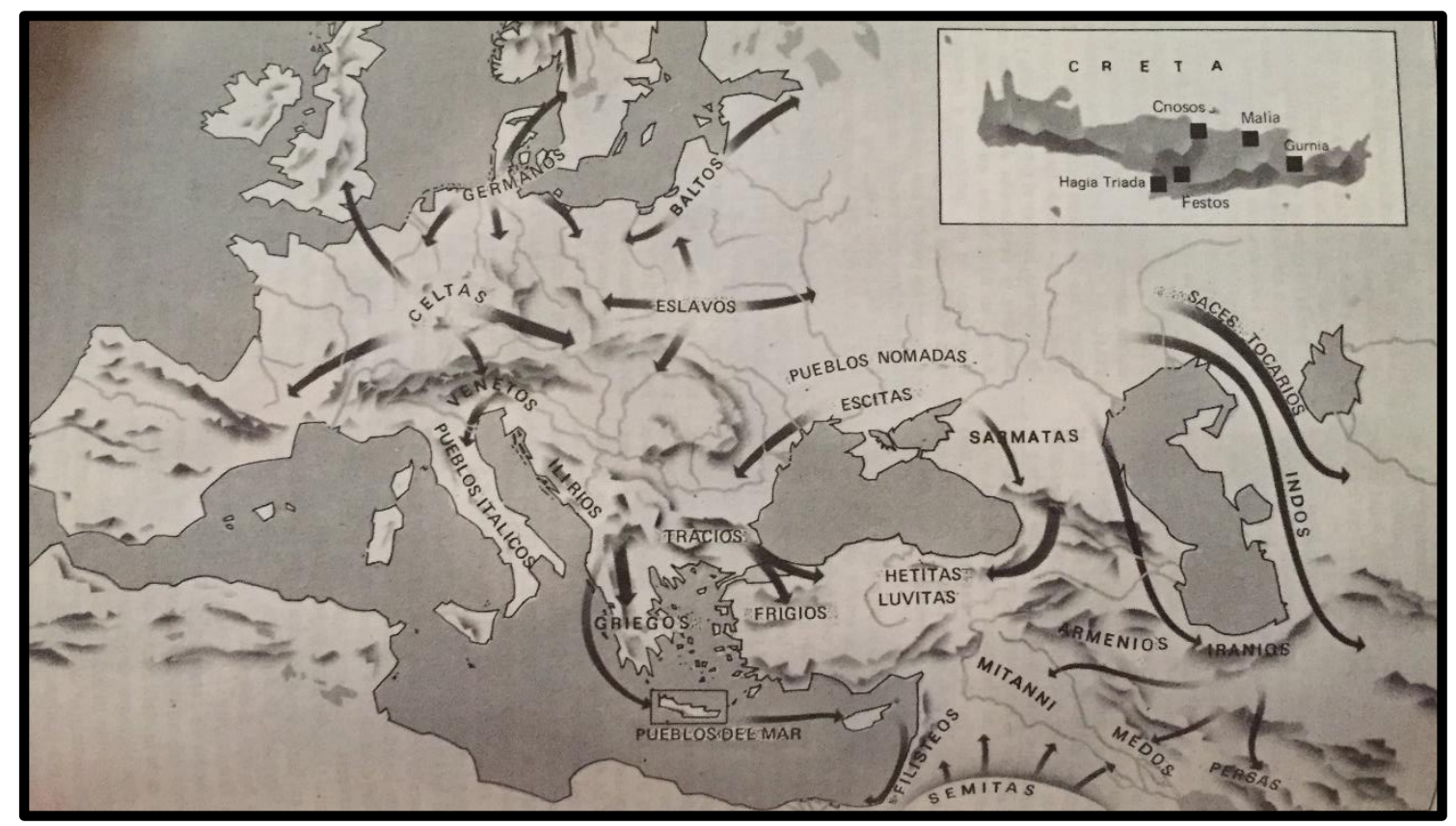

Primeras civilizaciones / Pueblos indoeuropeos. Creta (2600-1425 a.C.) ${ }^{63}$

- (...) hay otros dos o tres cosas más en Armenia que es importante (...) para conocer, digamos Maderaterán, ¿sabes qué es Maderaterán? Donde escritos antiguos que hay un monumento grande ahí. La puerta es Moisés [...] todo antigüedades están ahí.

Y sigue cantando.

\footnotetext{
${ }^{63}$ Kinder, H. Hilgelmann, W. Op. Cit.
} 


\section{Voces y territorios}

¿Castigo y venganza es lo mismo? ¿Castigo y reparación? ¿Justicia?

"Matarlos a todos".

Lo que dice Dikrauni es lo que sentencia un sobreviviente. Hoy, "todos" están muertos.

Guiragoz creyó que la política resolvería el problema, pero la política se sostiene en el conflicto.

Armen se negaba a comer con los jóvenes turcos amigos de su nieto, pero al hacerlo lograron superar el negacionismo.

Guiragoz, el que vivió en un orfanato, ¿pudo haber quedado allí contando y cantando la gran historia armenia?

Dependiendo de cómo nos vamos subjetivando en la trama de la cuestión de la armenidad, no podemos, todos, acercarnos a la idea del ser armenio en el otomanismo y después. En todo caso, frente a eso también hay una construcción de identidad en conflicto y eso es violencia. ¿Por qué? Porque el negacionismo hace de la armenidad una hipótesis, hace que en muchos casos siga siendo una pregunta, ¿Qué es la armenidad? ¿Qué es ser armenio?

La diáspora armenia necesita otros mecanismos para regresar y elaborar la armenidad sin negación; un tratado, un protocolo, una sentencia no son suficientes. Cuando turcos y armenios pongan fin al negacionismo el territorio alzará su voz y las voces que partieron de allí se seguirán escuchando una y otra vez, como lo estamos haciendo ahora con

Guiragoz;

Recuerdo, me voy a Recoleta, hay un lugar donde vino tres músicos turcos. Me dijo un sobrino que había ido, jandá a ver lo que son esos tres músicos! Voy ahí, Centro Recoleta, un rincón al lado de la Iglesia. Uno que tocaba el /dumbek/, otro tocaba la caña, y otro [golpea la mesa] la cítara. El que tocaba, eh, el /dumbek/, jay qué voz que tenía, /amán, amán, amán/! Habrán invitados turcos ahí. mí me salía de adentro, /iashá/! 
decía yo, de adentro. Una vez que terminan esto, le voy a dar un beso a cada músico, entonces, no volvían los músicos, y veo que sale un señor alto dice es el embajador turco, alto, embajador. Me mira. Yo soy Guiragoz Dermendjian, le digo yo. Nací en Marash, ah”, Amán, [dice algunas palabras en turco]), “qué bien hablás en turco”, me dice el embajador. Me felicitó, dice qué bien que hablas el turco, ¿no fuiste a Marash?, le digo yo. No, él me dice a mí, jsi yo fui a Marash!! [dice algo en turco y ríe].

Dikrauni:

- Yo hablaba en armenio por el colegio, porque a mi papá a la maestra de daba un caramelo por día (y le decía): "dale a mi hija, que lo coma, que sepa que cuando hay armenio... en la boca puede hablar, si puede hablar, entonces va a comer caramelo, sino no lo va a comer", y yo por el caramelo, me esforzaba y hablaba en armenio.

- $\quad$ Con mi mamá hablábamos en turco... Sí, eh, es una lucha, ¿eh? Es difícil, hablar con una persona un idioma, después hablar con el otro. Pero a mí en la escuela, los caramelos me habian hecho mucho bien. [risas]

Armen:

- Acá. Tengo nieto que viaja. El hijo mayor de mi hija, tiene veintinueve años ahora. Conjunto tiene, tango está muy de moda, lo llaman, pago, hotel pago, comida pago, todo pago, encima pagan a ellos también. Y se va. Conoció todo Europa y a unas personas turcas.

- Recibimos acá, porque él conoció turcos y cuando les dio la dirección y vinieron acá, invitamos a cenar. Y /olma mal' eld' amma old'/ (en turco: no tendría que haber pasado, pero pasó), dijeron, por la guerra.

Escucharlos regresando al territorio ancestral como lo hicimos en el encuentro final con Guiragoz. 


\section{Reflexiones}

"El odio y resentimiento que impulsaron un crimen en masa tal como genocidio fueron intensificados, en este caso, no por el pensamiento racista moderno sino por el contexto cultural del Islam otomano. Además, la existencia de grupos musulmanes no turcos y la dificultad de definir la "turquidad" única con criterios claros y evidentes condujo a los unionistas hacia un nacionalismo cultural. La tradición heredada de construcción y exclusión de la "otredad" social con fundamentos religiosos y no racistas fue lo que permitió esta transformación en términos filosóficos. Como resultado los unionistas fueron capaces de reconocer el derecho a la vida del "otro" pero solo cuando el "otro" abandonaba su "otredad". ${ }^{64}$

Viajar a Turquía sería una opción válida para conocer los pueblos natales de quienes dieron origen a la diáspora armenia. Pero no es la opción que elijo como consecuencia del bloqueo entre ambos países para acceder a la tierra de nuestros abuelos. La armenidad que se enterró para construir la turquidad puede "liberarse" de otro modo.

Yo pude, a través de este trabajo, visitar Yozgat, también Kutahya, Cesárea y Marash, pero sin pisar su tierra, desenterrándola. Pude cruzar desde Armenia a Turquía como un acto de reparación simbólica, cruzar desde el Memorial de Dzitsernagapert al Monte Ararat.

La puesta en valor del silencio y de las voces de archivo que provienen de los lugares de la llamada Armenia histórica occidental contrarrestan la violencia del negacionismo. Presentar la cuestión de la lengua como parte de la identificación con el territorio es parte del mismo propósito.

${ }^{64}$ Akçam, Taner Op. Cit. 
Mostrar las entrevistas que descendientes de armenios le realizaron a sobrevivientes del genocidio es visibilizar el acto de entrega de un legado. La recreación de esos encuentros otorga un marco performático que permite esa herencia; el acceso a esas tierras.

Los mapas no se presentan aquí como herramientas de estudio del pasado sin más, son aquí herramientas para leer y escuchar. La literalidad no es amiga del derecho a regresar. El derecho a regresar se transita en este trabajo a partir de la posibilidad de acceder a través de un testimonio a su lugar de memoria, algo que no requiere pasaporte, ni permisos, ni desbloqueos más que de nosotros mismos.

Tampoco dependemos de memoriales o vestigios de un patrimonio material que ha podido conservarse, apropiarnos del territorio es un ejercicio político-poético. 


\section{BIBLIOGRAFÍA}

Akcam, Taner "El crimen de Lesa Humanidad de los Jóvenes Turcos" El genocidio armenio y la limpieza étnica en el Imperio Otomano. Buenos Aires, Eduntref Prometeo, 2016.

Akcam, Taner (2010) Un acto vergonzoso. El genocidio armenio y la cuestión de la responsabilidad turca. Bs. As. Colihue.

Alem, Jean Pierre, “Armenia” Eudeba. Biblioteca Asia y África, Buenos Aires, $19833^{\circ}$ edición.

Arlen, Muchael. "Pasaje al Ararat" Buenos Aires, 1978.

Arzoumanian Ana, "El depósito humano" Una geografía de la desaparición. Buenos Aires, Xavier Bóveda Ed. 2010

Arzoumanian, Ana, "Hacer violencia" Nahuel Cerrutti Carol Editor Cuadernos para el Arte, Buenos Aires, 2014.

Arzoumanian, Ana "Infieles", Buenos Aires, Libros del Zorzal, 2017.

Bedrossian, Eduardo, “Morir en Marash” Ediciones. Buenos Aires, 2004.

Blanco, Marina, Levin, Florencia Comp. "Historia Reciente Perspectivas y Desafíos para un campo en construcción”, Paidós, Buenos Aires, 2007.

Boulgourdjian-Toufeksián, Nélida. Los armenios en Buenos Aires. La reconstrucción de la identidad (1900/1950). Agencia Periodística, Diario del Viajero. Buenos Aires. 1997. 
Boulgourdjian-Toufeksián, Nélida. "El Genocidio Armenio en la Prensa Argentina", Tomo I y II, Editorial Plus Ultra, Buenos Aires, 1988.

Butler Judith, "Vida precaria. El poder del duelo y la violencia" Buenos Aires, Paidós espacios del saber 2009 reimpresión.

Clarck, Frank, Jonassohn, Kurt" Historia y Sociología del genocidio. Análisis y estudio de casos" Eduntref Prometeo Colección estudios sobre genocidio, Buenos Aires, 2010.

Dadrian, Vahakn N. Los elementos clave en el negacionismo turco del genocidio armenio. Un estudio de distorsión y falsificación. Zoryan Instituto de Canadá y Fundación Armenia de Buenos Aires, Buenos Aires, 1999.

Derogy, Jacques, Operación Némesis, Francia, Fayard, 1986.

Despouy, Leandro. “El derrumbe del negacionismo” Planeta, Buenos Aires, 2009.

Feierstein Daniel Genocidio: La administración de la muerte en la modernidad EDUNTREF. 2005.

Granovsky, Súlim, "El genocidio silenciado" Holocausto del pueblo armenio. Ediciones Continente, Buenos Aires, 2014.

Guelerman, Sergio Comp. "Memoria en presente. Identidad y transmisión en la Argentina posgenocidio". Norma ed, Buenos Aires, 2001.

Huyssen, Andreas "En busca del futuro perdido" Cultura y memoria en tiempos de globalización, México, Fondo de Cultura Económica, 2002 
Instituto Espacio para la Memoria, "Manual para víctimas y testigos en causas vinculadas al Terrorismo de Estado" Buenos Aires, 2012.

Kuyumciyan, Rita. "El primer genocidio del siglo XX" Regreso de la memoria armenia. Planeta, Buenos Aires, 2009.

Matiossian, Vartan. Pasado sin retorno, futuro que espera. Los armenios en la Argentina, ayer y hoy. Uruguay, Ediciones Ascua Asociación cultural Uruguay Armenia, 2011.

Mendiola Gonzalo, Ignacio comp. "Rastros y rostros de la biopolítica "Barcelona, Anthropos, 2009.

Ohanian, Pascual, La Cuestión Armenia y las Relaciones Internacionales, 4 Tomos, Institución Armenia de Cultura Arshak Chobanian, Buenos Aires, 1994.

Ohanian, Pascual, Turquía, Estado genocida. Tomo I. Buenos Aires, 1986.

Oxman, Claudia. "La entrevista de investigación en Ciencias Sociales", Buenos Aires, UBA, 1998.

Ricoeur, Paul. "Memoria y verdad” FCE, Buenos Aires, 1era versión en español 2015.

Shamlian, A. "Memorias de Alta Armenia", Buenos Aires, Garabed Ekshian ed, 1965.

Tagtachian, Magda. "Nomeolvides. La historia de mi abuela armenia. Armenhui" Sudamenricana, Buenos Aires, 2016.

Traverso, Enzo "El pasado, instrucciones de uso" Prometeo libros. Historia, Memoria, Política, Buenos Aires, 2011. 
Varela, Brisa "Los rostros de Haik: memoria, migración e identidades a principios del siglo XXI” FLACSO Argentina DOCTORADO EN CIENCIAS SOCIALES 2006

VVAA Armenia, una presencia milenaria en la Argentina, Manrique Zago Ed, Buenos Aires, 1999.

VVAA "Buenos Aires Armenia" Temas de Patrimonio Cultural Tomo 28 Ministerio de Cultura CABA, 2010.

VVAA Diálogos, Identidades y postconflicto. Milena cacerola, Buenos Aires, 2015.

VVAA El genocidio armenio, el Primer Holocausto del siglo XX, Ediciones de la UGAB. Buenos Aires, 1982.

VVAA El genocidio armenio en la prensa del Uruguay año 1915, Ediciones ANI. Montevideo, 1985.

Zaffaroni, Eugenio Raúl (Estudio preliminar). "Un proceso histórico. Absolución al ejecutor del genocida turco Talaat Pasha”, Ediar, Buenos Aires, 2012.

Zizek, Slavoj, Jameson, Fredroc "Estudios culturales sobre el multiculturalismo" Paidós, Buenos Aires, 1998.

Páginas Web https://www.institut-geopoetique.org/es/articulos/214-breve-introduccion-a-lageopoetica

www.genocidioarmenio.org 
https://jrimian.edu.ar/

http://fmgenocidioarmenio.org.ar/

http://www.raoulwallenberg.net/es/holocausto/articulos-65/genocidio/raphael-lemkinpadre

https://www.cipdh.gob.ar/memorias-situadas/

http://verdadyjusticia.org.ar/fundacion/

http://www.diarioarmenia.org.ar/la-visita-del-papa-francisco-a-armenia-sera-muyintensa/

http://www.genocide-museum.am/eng/index.php

Artículos periodísticos

https://www.infobae.com/2016/05/21/1812752-viaje-la-guerra-olvidada-nagornokarabaj/

http://www.lavanguardia.com/internacional/20091010/53802315107/turquia-yarmenia-dan-un-paso-historico-para-resolver-su-largo-enfrentamiento.html

http://www.diarioarmenia.org.ar/los-protocolos-son-pasado-armenia-rompe-el-acuerdocon-turquia/

https://www.diarioarmenia.org.ar/resumen-de-la-guerra-de-artsaj-y-el-acuerdo-firmado.

https://www.diarioarmenia.org.ar/ochenta-y-cinco-anos-de-hom-sudamerica/ 